\title{
Characters and phylogenetic relationships of nectar-feeding bats, with descriptions of new Lonchophylla from western South America (Mammalia: Chiroptera: Phyllostomidae: Lonchophyllini)
}

\author{
Neal Woodman* and Robert M. Timm \\ (NW)USGS Patuxent Wildlife Research Center, National Museum of Natural History MRC- \\ 111, Smithsonian Institution, Washington, DC 20013-7012, U.S.A., e-mail: woodmann@si.edu; \\ (RMT) Natural History Museum, University of Kansas, Lawrence, Kansas 66045-7561, U.S.A., \\ e-mail: btimm@ku.edu
}

\begin{abstract}
The Neotropical Lonchophyllini (Chiroptera: Phyllostomidae) currently comprise four genera and thirteen species of nectar-feeding bats. These species often are separated into larger-bodied (eight species) and smaller-bodied (five species) forms to aid in identification. Our morphological and morphometrical analyses of the smaller Lonchophyllini revealed the existence of two distinctive, previously undescribed species of bats of the genus Lonchophylla from western South America. We describe a new form from Amazonian Peru as Lonchophylla pattoni and one from western Colombia as Lonchophylla cadenai. Phyllogenetic analysis of the Lonchophyllini based primarily on morphological characters indicates that these two new species are closely related to Lonchophylla thomasi.
\end{abstract}

Nectar-feeding bats of the Neotropical genus Lonchophylla (Chiroptera: Phyllostomidae) occur primarily in tropical lowland and mid-elevation forests from near sea level to at least $1350 \mathrm{~m}$ and have a geographic distribution that extends from southern Nicaragua south into southern Peru, Bolivia, and southeastern Brazil (Koopman 1994, Anderson 1997). Ten species of Lonchophylla currently are recognized (Dávalos 2004, Albuja \& Gardner 2005). Recent phylogenetic analyses, based on mitochondrial DNA and morphological characters, suggest that Lonchophylla may be paraphyletic with respect to the monotypic genera Lionycteris, Platalina, and Xeronycteris (Dávalos \& Jansa 2004, Gregorin \& Ditchfield 2005). Although the relationships among these genera and their respective species require further resolution, the consensus

\footnotetext{
* Corresponding author.
}

is that these highly specialized nectarfeeding bats comprise a cohesive monophyletic lineage that merits formal taxonomic recognition, either at the level of tribe (Lonchophyllini) within the subfamily Glossophaginae (Wetterer et al. 2000, Carstens et al. 2002, Baker et al. 2003, Simmons 2005), or as its own subfamily (Lonchophyllinae - Griffiths 1982; Koopman 1993, 1994).

During field work along the lower Río Madre de Dios in southeastern Peru, James L. Patton captured a single adult male Lonchophylla, and we subsequently collected two additional individuals nearby at Cusco Amazónico (Woodman et al. 1991). Two of these three specimens are easily identifiable as typical $L$. thomasi. Although the third specimen has a number of characteristics that suggest a close relationship with $L$. thomasi, it differs significantly from that species in cranial characters, in size, and in pelage colora- 
tion. It clearly represents a species new to science. While studying this specimen and attempting to characterize $L$. thomasi from western South America, we encountered a second distinctive sample of small Lonchophylla from southwestern Colombia. This population represents another previously unrecognized species that is morphologically close to, yet distinct from, L. thomasi. Herein, we describe these two as new species and review the morphology of $L$. thomasi and the other small species of Lonchophyllini.

\section{Materials and Methods}

All measurements presented herein are in millimeters, and weights are given in grams. Forearms and crania were measured with dial or digital calipers to the nearest $0.1 \mathrm{~mm}$. External measurements, other than length of forearm, are those recorded on specimen labels or in field notes by the original collectors. Length of head and body was determined by subtracting tail length from total length. Length of forearm (FA) was measured from the most proximal point of the ulna to the most distal point of the carpals with the wing flexed. Skull measurements (with their abbreviations) are illustrated in Fig. 1. These variables were measured to the nearest $0.1 \mathrm{~mm}$ using a digital caliper or an ocular micrometer in a dissecting microscope (for PL). Capitalized color terms are from Ridgway (1912). Pelage colors are based on museum specimens collected over more than a century's span that have experienced a variety of storage conditions, and they may not accurately reflect the color of live animals or of freshly prepared specimens. In descriptions of habitats, capitalized vegetational associations are from the Holdridge system for classification of life zones (Holdridge 1947, Tosi 1960, Holdridge et al. 1971).

As noted previously, the two species that we describe herein are most similar in size and morphology to L. thomasi, with which they initially were confused. To detect possible geographic variation in $L$. thomasi, we carried out principal components analyses (PCA) using 115 individuals from Bolivia $(n=3)$, Brazil (19), Colombia (5), Ecuador (4), French Guiana (5), Guyana (9), Panama (11), Peru (36), Suriname (10), and Venezuela (13). We then plotted their resulting factor scores separately by country or region (in the case of the Guianas) and inspected the plots for apparent trends. To investigate morphometrical relationships of $L$. thomasi with the two new species, we carried out PCAs comparing (1) the holotype of the new species of Lonchophylla from Cusco Amazónico with 15 female and 21 male $L$. thomasi from throughout Peru, and (2) five specimens of the new species from Colombia with 41 female and 71 male $L$. thomasi from throughout that species's distribution. For all PCAs in this study, we used a 10-variable model (GLS, $\mathrm{PL}, \mathrm{PO}, \mathrm{ZB}, \mathrm{BB}, \mathrm{MB}, \mathrm{TR}, \mathrm{MM}, \mathrm{HCP}$, FA).

To assist us with understanding intraspecific and interspecific variation among the Lonchophyllini, we investigated sexual dimorphism by comparing individual variables within selected samples. For $L$. thomasi, we used a pooled sample from throughout the geographical distribution of the species ( 35 females, 65 males), as well as geographically constrained subsamples from Brazil (6 females, 10 males), Panama (4 females, 7 males), and Peru (15 females, 22 males). We also tested Lonchophylla mordax from Brazil (15 females, 7 males) and Lionycteris spurrelli from Venezuela (9 females, 9 males). We tested selected variables for statistical significance using Student's $t$ tests for small or large samples of equal or unequal size, as appropriate (Sokal \& Rohlf 1981). We further investigated sexual dimorphism in $L$. thomasi in multivariate space by comparing factor scores between males and females from 

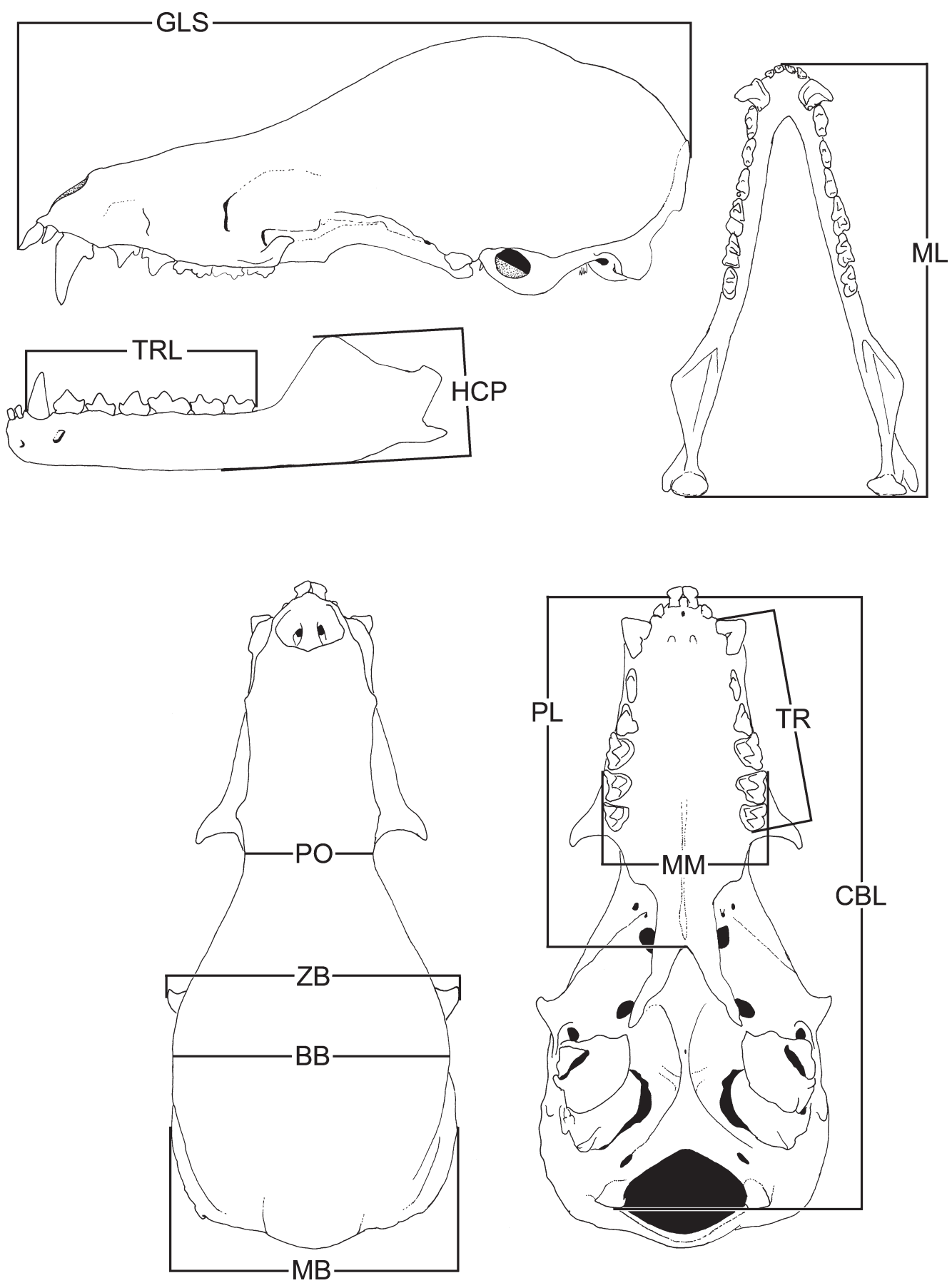

Fig. 1. Lateral and dorsal views of the cranium and mandible, and ventral view of the cranium, illustrating measurements used in this study: breadth of braincase (BB); condylobasal length (sensu Thomas 1905-CBL); greatest length of skull, including incisors (GLS); height of coronoid process of mandible (HCP); mastoid breadth (MB); length of mandible (ML); breadth across upper molars (MM); palatal length (PL); breadth at postorbital constriction (PO); length of maxillary toothrow, C1-M3 (TR); length of mandibular toothrow, c1-m3 (TRL); zygomatic breadth (ZB). 
the 112 sexed individuals from our PCA for geographic variation. We plotted females and males separately on PC 1, PC 2, PC 3, and PC 4, and we visually inspected the plots for patterns of differentiation.

We investigated the phylogeny of the Lonchophyllini (Lionycteris, Lonchophylla, Platalina, and Xeronycteris) by using the computer program PAUP 4.0b10 for Macintosh computers (Swofford 1998) to analyze a matrix of 65 characters. This dataset (Appendix 1) included 26 morphological and mDNA restriction site characters from the analysis by Wetterer et al. (2000) of Phyllostomidae, as well as 7 from Gregorin \& Ditchfield (2005). We used the original codings of Wetterer et al. (2000), except for their characters 12 and 21, for which we followed Dávalos \& Jansa (2004). For some species of Lonchophyllini not investigated by Wetterer et al. (2000), we relied upon codings reported by Carstens et al. (2002), Dávalos \& Jansa (2004), Gregorin \& Ditchfield (2005), and our own determinations using available specimens. In some cases, scorings could not be verified. Carstens et al. (2002), for example, scored characters 77 and 104 for five species of Lonchophylla. According to their published methodology, however, their scorings of soft-tissue characters were based on Wetterer et al. (2000) and Carstens et al. (2002:27), who derived them from Griffiths (1982) and Benedict (1957), who studied only a single species of the genus, L. robusta. In such cases, we scored only the original species studied. Carstens et al. (2002), Dávalos (2004), Dávalos \& Jansa (2004), and other authors used the name $L$. mordax for specimens we now consider to be $L$. concava. We concur with Albuja \& Gardner (2005) that the two names represent distinct species, and we adjusted the data matrix accordingly. Specimens of L. bokermanni, L. orcesi, and Xeronycteris vieirai were unavailable to us, and, whenever possible, we inferred characters from the original descriptions and accompanying illustrations (Sazima et al. 1978, Albuja \& Gardner 2005, Gregorin \& Ditchfield 2005). In our analyses, all characters were equally weighted and unordered. Previous analyses of the Phyllostomidae (Baker et al. 2000, 2003; Wetterer et al. 2000; Carstens et al. 2002) suggested a variety of complex relationships between the Lonchophyllini and other groupings of phyllostomids. To encompass as many potential outgroup relationships as possible, we included in our outgroup seven species inferred to have relatively close relationships with Lonchophyllini (subfamilial and tribal affiliations follow Simmons 2005): $A n$ oura geoffroyi, Glossophaga soricina, and Monophyllus redmani (Glossophaginae, Glossophagini), Carollia perspicillata (Carolliinae), Erophylla sezekorni and Phyllonycteris poeyi (Phyllonycterinae), and Brachyphylla cavernarum (Brachyphyllinae). No topology for the outgroup was enforced. We used parsimony analysis with the heuristic search option and a random addition sequence of 1000 replicates. Starting trees were via stepwise addition, and the branch-swapping algorithm was tree-bisection-reconnection (TBR). We also carried out a bootstrap analysis of 1000 replicates with a random addition sequence of 100 replicates and TBR. We analyzed character evolution on the resultant trees using MCCLADE 3.0 (Maddison \& Maddison 1992).

A list of specimens examined is presented in Appendix 2. We made use of specimens from the following collections (abbreviations in parentheses): American Museum of Natural History, New York (AMNH); Carnegie Museum of Natural History, Pittsburgh (CM); Joseph Moore Museum, Earlham College, Richmond (EC); Field Museum of Natural History, Chicago (FMNH); University of Kansas Natural History Museum, Lawrence (KU); Los Angeles County Museum, 
Los Angeles (LACM); Louisiana State University Museum of Zoology, Baton Rouge (LSU); Museum of Southwestern Biology, Albuquerque (MSB); Michigan State University, East Lansing (MSU); Museum of Vertebrate Zoology, Berkeley (MVZ); Museum of Texas Tech University, Lubbock (TTU); University of Michigan Museum of Zoology, Ann Arbor (UMMZ); National Museum of Natural History, Washington (USNM).

\section{Results}

Characteristics of the Lonchophyllini.Species of Lionycteris, Lonchophylla, Platalina, and Xeronycteris share a number of distinctive morphological characteristics that include lateral lingual sulci; single line of hairlike papillae ventral to lingual sulcus; three interramal vibrissae; incomplete zygomatic arches; shallow glenoid fossa; spatulate first upper incisors that are much larger than second upper incisors; upper canine separated from the second incisor and from the third premolar by conspicuous spaces; and well-developed lower incisors that are (except in Platalina) tricuspid (Wetterer et al. 2000, Gregorin \& Ditchfield 2005).

The dental formula in the Lonchophyllini is typically i $2 / 2, \mathrm{c} 1 / 1, \mathrm{p} 2 / 3, \mathrm{~m} 3 / 3 \times 2$ $=34$. Phillips (1971), however, reported the presence of a small, simple, and single-rooted P2 in some individuals of Lonchophylla concava and L. robusta. In a sample of 137 specimens of $L$. thomasi we examined for this character, 2 specimens from Panama have this additional tooth on both maxillae and 1 specimen from Peru has it on just one side. Among 40 L. concava, 1 of 9 specimens from Colombia, 1 of 9 from Costa Rica, 5 of 7 from Ecuador, and 2 of 15 from Panama possess P2. One of 5 specimens of $L$. hesperia has $\mathrm{P} 2$ on both sides. No specimens of L. chocoana $(n=3)$, L. dekeyseri (3), L. handleyi (4), L. mordax (26), or of either of the new species (6) possess the tooth. Because of its simplicity, an atavistic P2 might be mistaken for a retained deciduous premolar. However, one young $L$. concava from Colombia (USNM 434372) possesses both $\mathrm{P} 2 \mathrm{~s}$ and a left deciduous premolar between $\mathrm{P} 2$ and $\mathrm{C} 1$. The deciduous premolar has a long, strongly recurved tip that tapers gradually to a point, whereas the atavistic P2 has a shorter, uncurved, more abruptly pointed tip that is similar in shape to the main cusps on P3 and P4.

The Lonchophyllini exhibit generalized tendencies of elongation of the skull and rostrum and reduction of the dentition from Lionycteris to Lonchophylla to Platalina to Xeronycteris. The four genera can be distinguished from one another based on the characteristics provided in the following synopses.

\section{Lionycteris Thomas, 1913}

Type species. - Lionycteris spurrelli Thomas, 1913. The genus is monotypic.

Description.-Pelage differentiated into over hair and under hair; majority of hair scale margins toothed (rather than entire); dorsal pelage monocolored (rather than distinctly bicolored); genal vibrissae present as single hairs; central rib of noseleaf restricted to proximal part of spear; line of papillae in internarial region of noseleaf; tongue with basket-like medial-posterior mechanical papillae. Skull short; rostrum short relative to braincase; upper post-canine toothrows converge anteriorly; P3 and P4 short and triangular (rather than elongate and laterally compressed), each possesses obvious, rooted lingual cusp (protocone?), low but distinct parastyle, and high paracone; upper molars broadly quadratic to broadly triangular in outline, anterior and lateral borders form ca. $90^{\circ}$ angle; M1 and M2 with $\mathrm{W}$ shaped ectoloph, mesostyle, metastyle, postprotocrista, distinct parastyle not anterior to paracone, small hypoconal 
and sometimes a small hypoconal basin; M3 located entirely dorsal to base of anterior zygomatic process. Dentary relatively short; lower incisors tricuspid; gap between i2 and $\mathrm{c} 1$ small, less than length of i2; c1 with cingulum; p2-p4 short, broad; p2 possesses small paraconid; p3 and $\mathrm{p} 4$ possess small metaconid; $\mathrm{m} 1$ in contact, and often overlapping with, p4; $\mathrm{m} 1, \mathrm{~m} 2$, and $\mathrm{m} 3$ possess distinct entoconid.

\section{Lonchophylla Thomas, 1903}

Type species.-Lonchophylla mordax Thomas, 1903. There are twelve species, including the two we describe herein.

Description.-Pelage differentiated into over hairs and under hairs; majority of hair scale margins entire; dorsal pelage distinctly bicolored; genal vibrissae absent or present as double hairs; central rib of noseleaf restricted to proximal part of spear; line of papillae in internarial region of noseleaf; tongue with basket-like medial-posterior mechanical papillae. Skull long; rostrum long relative to braincase; upper post-canine toothrows converge anteriorly; P3 and P4 elongate and laterally compressed, each possesses low but distinct parastyle and high paracone; P3 lacks lingual cusp; P4 may possess or lack lingual cusp; upper molars broadly triangular to broadly quadratic in outline, anterior and lateral borders form acute angle; M1 and M2 with W-shaped ectoloph, mesostyle, metastyle, postprotocrista, and distinct parastyle located anterior to paracone; M1 and M2 may or may not possess hypocone, posthypocrista, and hypoconal basin; part of M3 anterior to base of zygomatic process. Dentary relatively long; lower incisors tricuspid; gap between i2 and c1 small to large, at least as long as length of i2; c1 with cingulum; p2-p4 long, narrow; p2 lacks paraconid; p3 and p4 lack metaconid; $\mathrm{m} 1$ in contact, and often overlapping with, $\mathrm{p} 4 ; \mathrm{m} 1-\mathrm{m} 3$ possess distinct entoconid.
Platalina Thomas, 1928

Type species.-Platalina genovensium Thomas, 1928. The genus is monotypic.

Description.-Pelage undifferentiated, over hairs absent; majority of hair scale margins entire; dorsal pelage distinctly bicolored; genal vibrissae absent; central rib of noseleaf absent; internarial region of noseleaf smooth; basket-like medialposterior mechanical papillae absent from tongue. Skull long; rostrum long relative to braincase; upper post-canine toothrows parallel (rather than converging anteriorly); P3 and P4 elongate and laterally compressed, each with low parastyle and low paracone and lacking an accessory lingual cusp; upper molars narrowly triangular in outline, anterior and buccal borders form acute angle; M1 and M2 each have reduced postprotocrista, and lack W-shaped ectoloph, parastyle, mesostyle, metastyle, hypocone, and hypoconal basin; M3 located entirely anterior to zygomatic process. Dentary long; lower incisors bicuspid (rather than tricuspid); gap between i2 and $\mathrm{c} 1$ large, at least as long as length of i2; c1 with cingulum; $\mathrm{p} 2, \mathrm{p} 3$, and $\mathrm{p} 4$ long, narrow; p2 lacks paraconid; p3 and p4 lack metaconid; gap present between $\mathrm{p} 4$ and $\mathrm{m} 1 ; \mathrm{m} 1, \mathrm{~m} 2$, and $\mathrm{m} 3$ lack entoconid.

Xeronycteris Gregorin \& Ditchfield, 2005

Type species.-Xeronycteris vieirai Gregorin \& Ditchfield, 2005. The genus is monotypic.

Description.-Few aspects of the pelage or soft anatomy of this recently recognized genus have been described. Central rib of noseleaf absent; internarial region of noseleaf smooth; basket-like medialposterior mechanical papillae absent from tongue. Skull long; rostrum appears long relative to braincase; upper post-canine toothrows converge anteriorly; P3 and P4 elongate and laterally compressed, each with large parastyle and low paracone, and lacking lingual cusp; upper molars 
extremely narrow, roughly $\mathrm{T}$-shaped in outline; M1 and M2 with distinct parastyle anterior to paracone, and lacking Wshaped ectoloph, mesostyle, metastyle, and postcentrocrista; M3 located far anterior to zygomatic process. Dentary long; lower incisors tricuspid; gap between i2 and c1 large, at least as long as length of i2; c1 lacks cingulum; p2, p3, and $\mathrm{p} 4$ long, narrow; $\mathrm{p} 2$ lacks paraconid; p3 and p4 lack metaconid; gap present between $\mathrm{p} 4$ and $\mathrm{m} 1 ; \mathrm{m} 1, \mathrm{~m} 2$, and $\mathrm{m} 3$ lack entoconid.

Characteristics of the smaller species of Lonchophyllini.-The ten species of Lonchophylla currently recognized generally are divided into two size groupings based on greatest length of skull (GLS; Taddei et al. 1983, Dávalos 2004). Because species in the genus differ to some extent in the relative length of the rostrum, GLS does not always accurately represent relative body size or consistently reflect other measures of size commonly used for bats. For example, among a sample of $100 \mathrm{~L}$. thomasi, the correlation coefficients of GLS with FA $(r=$ $0.378)$ and $\mathrm{HB}(r=0.376)$ were quite low. This size division also does not appear to reflect phylogenetic relationships within the genus (Dávalos \& Jansa 2004). However, the two groups are helpful for identifying species. "Large" species, with GLS $>24.5 \mathrm{~mm}$, include L. bokermanni, $L$. chocoana, $L$. handleyi, $L$. hesperia, $L$. orcesi, and $L$. robusta (Table 1$)$. The group of "small" species (GLS < $24.5 \mathrm{~mm}$ ) is composed of $L$. concava, $L$. dekeyseri, L. mordax, and L. thomasi. In addition, Lonchophylla may be paraphyletic with respect to the monotypic genera Lionycteris, Platalina (Baker et al. 2003, Dávalos \& Jansa 2004), and Xeronycteris (Gregorin \& Ditchfield 2005). Based on their respective GLS, Platalina genovensium and Xeronycteris vieirai group with the larger species of Lonchophylla, and Lionycteris spurrelli is included among the smaller species (Table 1). Because our specimens from southeastern Peru and southwestern Colombia represent smaller species of Lonchophyllini, we provide detailed comparisons of the new species only with those five species.

Lionycteris spurrelli Thomas, 1913 Spurrell's Long-tongued Bat

Figs. 2a, 3a, 4a

Type locality.- "Condoto, Choco, Colombia. Alt. 300" "(Thomas 1913:271).

Distribution.-Eastern Panama south to Peru and Brazil; elevational distribution up to $1400 \mathrm{~m}$ (Reid 1997).

Description.-Lionycteris spurrelli has a shorter skull and relatively shorter rostrum than any Lonchophylla, but a relatively longer body and forearm (Table 2). Dorsal pelage 4-5 $\mathrm{mm}$ in length, monocolored (bicolored in Lonchophylla), Cinnamon Brown to Bone Brown; ventral pelage paler, Wood Brown to Buffy Brown. In dorsal view, rostrum appears short and strongly inflated above M1s; lateral outlines of rostrum strongly convex; postorbital region slightly inflated, lacking lateral projections; posterior margin of infraorbital foramen not projecting beyond lateral outline of rostrum. Anterior edge of upper canine convexly rounded. In lateral view, posterior border of infraorbital foramen may be above posterior root of P4, but more typically between P4 and M1 or above anterior root of M1. In palatal view, obvious gap between I1 and I2; P3 and P4 short and triangular, rather than elongate and laterally compressed as among Lonchophylla; both P3 and P4 possess obvious, rooted lingual cusp (not present on P3 in Lonchophylla); upper molars large; postprotocrista of M1 and M2 joins posteriorly with hypocone and posthypocrista to form long ridge extending posterior to metacone, often forming small hypoconal basin; anterior and lateral borders of upper molars appear nearly straight, forming ca. $90^{\circ}$ angle and giving these teeth a more quadrate outline 
Table 1.- Ranges of selected measurements for species of the Lonchophyllini. Species are listed in decreasing order by maximum greatest length of skull.

\begin{tabular}{|c|c|c|c|c|c|c|c|}
\hline Species & $\begin{array}{l}\text { Greatest length } \\
\text { of skull }\end{array}$ & $\begin{array}{l}\text { Length of } \\
\text { forearm }\end{array}$ & $\begin{array}{l}\text { Length of head } \\
\& \text { body }\end{array}$ & $\begin{array}{l}\text { Length } \\
\text { of tail }\end{array}$ & $\begin{array}{l}\text { Length of } \\
\text { hind foot }\end{array}$ & $\begin{array}{l}\text { Length } \\
\text { of ear }\end{array}$ & Weight \\
\hline $\begin{array}{l}\text { Platalina genovensium } \\
\qquad(1 \text { female, } 3 \text { males })^{1,2}\end{array}$ & $27.5-33.7$ & $\begin{array}{l}47.5-52.0 \\
(n=3)\end{array}$ & $72-80$ & $6-9$ & $\begin{array}{l}11-13 \\
(n=3)\end{array}$ & $13-14$ & $\begin{array}{c}16.0-16.5 \\
(n=2)\end{array}$ \\
\hline $\begin{array}{l}\text { Lonchophylla orcesi } \\
\qquad(1 \text { female })^{3}\end{array}$ & 30.4 & 47.0 & 61 & 11 & 14.5 & 17 & 22.0 \\
\hline $\begin{array}{l}\text { Lonchophylla robusta } \\
\text { (29 females, } 21 \\
\text { males) })^{1}\end{array}$ & $\begin{array}{r}24.9-29.5 \\
(n=48)\end{array}$ & $\begin{array}{r}40.3-45.9 \\
(n=48)\end{array}$ & $\begin{array}{l}61-78 \\
(n=39)\end{array}$ & $\begin{array}{c}5-13 \\
(n=39)\end{array}$ & $\begin{array}{l}11-15 \\
(n=31)\end{array}$ & $\begin{array}{l}14-19 \\
(n=31)\end{array}$ & $\begin{array}{r}12.2-18.5 \\
(n=25)\end{array}$ \\
\hline $\begin{array}{l}\text { Lonchophylla chocoana } \\
\qquad(4 \text { females })^{1,4}\end{array}$ & $\begin{array}{l}27.2-28.3 \\
(n=2)\end{array}$ & $42.0-48.0$ & $67-74$ & $7-11$ & $12-15$ & $14-17$ & $\begin{array}{c}19.0-23.0 \\
(n=2)\end{array}$ \\
\hline $\begin{array}{l}\text { Lonchophylla handleyi } \\
\qquad(2 \text { female, } 6 \text { males })^{1}\end{array}$ & $27.0-28.0$ & $\begin{array}{l}44.9-47.0 \\
(n=7)\end{array}$ & $\begin{array}{l}65-81 \\
(n=7)\end{array}$ & $\begin{array}{c}5-7 \\
(n=6)\end{array}$ & $\begin{array}{l}10-14 \\
(n=7)\end{array}$ & $\begin{array}{c}17 \\
(n=7)\end{array}$ & $\begin{array}{c}12.0-21.0 \\
(n=6)\end{array}$ \\
\hline $\begin{array}{l}\text { Lonchophylla hesperia } \\
\text { ( } 3 \text { females, } 3 \text { males, } \\
2 \text { sex unknown })^{1,5}\end{array}$ & $\begin{array}{c}25.4-28.0 \\
(n=6)\end{array}$ & $38.0-40.6$ & $51-68$ & $7-13$ & $\begin{array}{c}8-15 \\
(n=4)\end{array}$ & $\begin{array}{l}10-15 \\
(n=6)\end{array}$ & $\begin{array}{c}10 \\
(n=2)\end{array}$ \\
\hline $\begin{array}{l}\text { Xeronycteris vieirai }(2 \\
\text { females, } 1 \text { male })^{1,6}\end{array}$ & $\begin{array}{l}25.5-27.0 \\
(n=2)\end{array}$ & $35.4-38.1$ & - & - & - & - & - \\
\hline $\begin{array}{l}\text { Lonchophylla } \\
\text { bokermanni ( } 7 \\
\text { females, } 2 \text { males) })^{1,7}\end{array}$ & $25.2-26.3$ & $38.7-41.3$ & $\begin{array}{l}60-65 \\
(n=7)\end{array}$ & - & $\begin{array}{c}8-9 \\
(n=8)\end{array}$ & - & - \\
\hline $\begin{array}{l}\text { Lonchophylla concava } \\
\qquad(6 \text { females, } 9 \text { males })^{1}\end{array}$ & $22.2-24.0$ & $32.3-34.7$ & $46-65$ & $5-10$ & $9-12$ & $5-17$ & $\begin{array}{l}7.0-9.0 \\
(n=10)\end{array}$ \\
\hline $\begin{array}{l}\text { Lonchophylla mordax } \\
\quad(15 \text { females, } 7 \text { males })\end{array}$ & $22.0-24.0$ & $33.5-37.8$ & $45-60$ & $8-14$ & $8-10$ & $13-16$ & $7.5-11.0$ \\
\hline $\begin{array}{l}\text { Lonchophylla dekeyseri } \\
\quad(4 \text { females, } 4 \text { males })^{1,8}\end{array}$ & $22.0-22.8$ & $34.0-37.7$ & $\begin{array}{l}48-63 \\
(n=5)\end{array}$ & $\begin{array}{c}6-8 \\
(n=2)\end{array}$ & $\begin{array}{l}10-11 \\
(n=2)\end{array}$ & $\begin{array}{l}12-16 \\
(n=2)\end{array}$ & $\begin{array}{c}9.0 \\
(n=2)\end{array}$ \\
\hline $\begin{array}{l}\text { Lonchophylla cadenai } \\
\qquad(5 \text { females, } 2 \text { males })^{1}\end{array}$ & $\begin{array}{l}21.4-22.5 \\
(n=6)\end{array}$ & $31.4-32.7$ & $\begin{array}{l}51-56 \\
(n=4)\end{array}$ & $\begin{array}{c}7-10 \\
(n=4)\end{array}$ & $\begin{array}{c}8-10 \\
(n=4)\end{array}$ & $\begin{array}{l}14-15 \\
(n=4)\end{array}$ & - \\
\hline $\begin{array}{l}\text { Lonchophylla pattoni } \\
\quad \text { (1 female) }\end{array}$ & 22.3 & 34.1 & 57 & 10 & 9 & 16 & 8.6 \\
\hline $\begin{array}{l}\text { Lonchophylla thomasi } \\
\qquad(35 \text { females, } 65 \\
\text { males })^{1}\end{array}$ & $19.5-22.2$ & $29.8-34.4$ & $42-61$ & $4-12$ & $6-11$ & $8-17$ & $\begin{array}{l}4.0-9.0 \\
(n=89)\end{array}$ \\
\hline $\begin{array}{l}\text { Lionycteris spurrelli (17 } \\
\text { females, } 10 \text { males) }\end{array}$ & $19.0-20.7$ & $33.4-37.5$ & $53-60$ & $6-9$ & $10-12$ & $8-14$ & $7.0-11.0$ \\
\hline
\end{tabular}

${ }^{1}$ Except as noted.

${ }^{2}$ Measurements from Thomas (1928) and Galaz et al. (1999).

${ }^{3}$ Measurements from Albuja \& Gardner (2005).

${ }^{4}$ Measurements from Dávalos (2004), plus USNM 483361, 483362.

${ }^{5}$ Includes measurements of male holotype and two other specimens from Allen (1908).

${ }^{6}$ Measurements from Gregorin \& Ditchfield (2005).

${ }^{7}$ Measurements from Sazima et al. (1978).

${ }^{8}$ Measurements from Taddei et al. (1983), plus MSU 16411, USNM 123392, 584472, 584473.

(more triangular in Lonchophylla); midline of central palate more highly domed than among smaller species of Lonchophylla; transition of posterior palate to postdental palate not interrupted by deep midline groove; palate posterior to M3 less than one-half length of M3; posteromedial edge of palate just anterior to, or at, posterior border of optic foramen; mesopterygoid fossa long, open, and Wshaped anteriorly; median projection of palate may extend posteriorly into mesopterygoid fossa; postero-lateral borders of postdental palate smoother, less obviously convex than in smaller species of Lonchophylla; pterygoid processes straight, nar- 


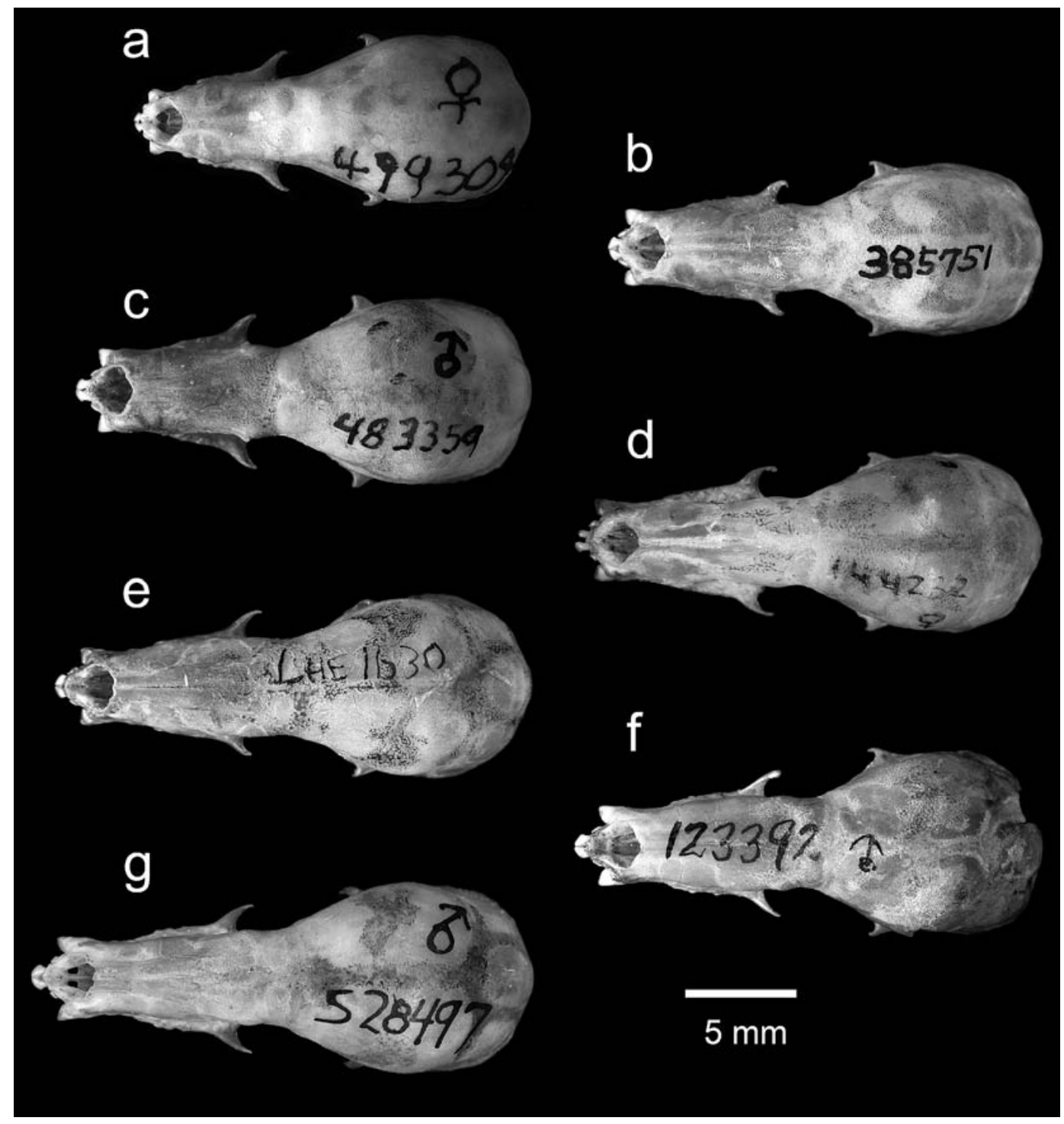

Fig. 2. Dorsal view of skulls of (a) Lionycteris spurrelli, (b) Lonchophylla thomasi, (c) L. cadenai, (d) L. pattoni, (e) L. dekeyseri, (f) L. mordax, and (g) L. concava. All photographs to same scale.

row, uninflated; basisphenoid pits shallow; septum between basisphenoid pits relatively broad, with rounded or flattened surface. Dentary relatively shorter than among species of Lonchophylla; coronoid process high (well above level of articular condyle), with narrowly rounded apex and deep upper sigmoid notch; articular process short; p2 with well-defined posterior cusp similar to that of $\mathrm{p} 3$; central cusps of $\mathrm{p} 3$ and $\mathrm{p} 4$ high and narrow, offset laterally in occlusal view from anterior and posterior cusps rather than in a row as in Lonchophylla. In dorsal view, gap between i2 and canine typically much narrower than length of i2.

Remarks.-A sample of 9 female and 9 male L. spurrelli from Venezuela exhibited no obvious indication of sexual dimorphism in size (Table 2: footnote 7). 


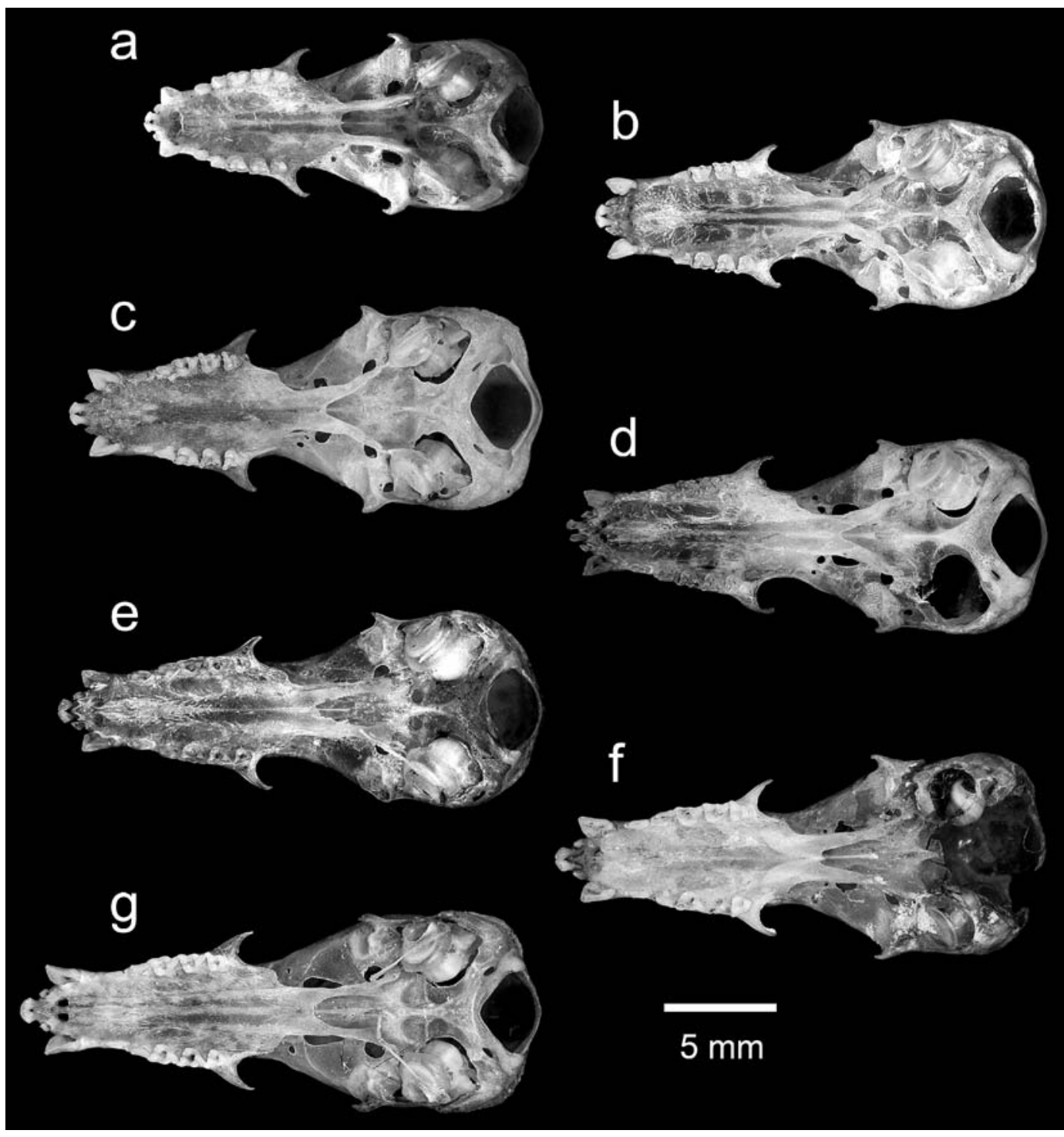

Fig. 3. Ventral view of skulls of (a) Lionycteris spurrelli, (b) Lonchophylla thomasi, (c) L. cadenai, (d) L. pattoni, (e) L. dekeyseri, (f) L. mordax, and (g) L. concava. All photographs to same scale.

Lonchophylla concava Goldman, 1914 Goldman's Nectar Bat

Figs. 2g, 3g, 4g, $11 \mathrm{~b}$

Type locality._ “Cana (altitude 2,000 feet)," Darién, eastern Panama.

Distribution.--Southern Costa Rica to Peru; elevational distribution to $600 \mathrm{~m}$ (Ascorra et al. 1994, Reid 1997).

Description.-Lonchophylla concava has relatively long GLS and $\mathrm{HB}$, but a rela- tively short FA (Table 2). Dorsal pelage 5-8 mm long, distinctly bicolored with paler bases (ca. 65\% of length) Drab Gray to Drab, dorsal portions Olive-Brown to Clove Brown; venter paler than dorsum, Light Drab to Wood Brown. Anterior edge of upper canine grooved by wear against lower canine. In dorsal view, rostrum long and narrow; rostrum slightly inflated above M1s, lateral outlines gently convex; postorbital region not inflated, 


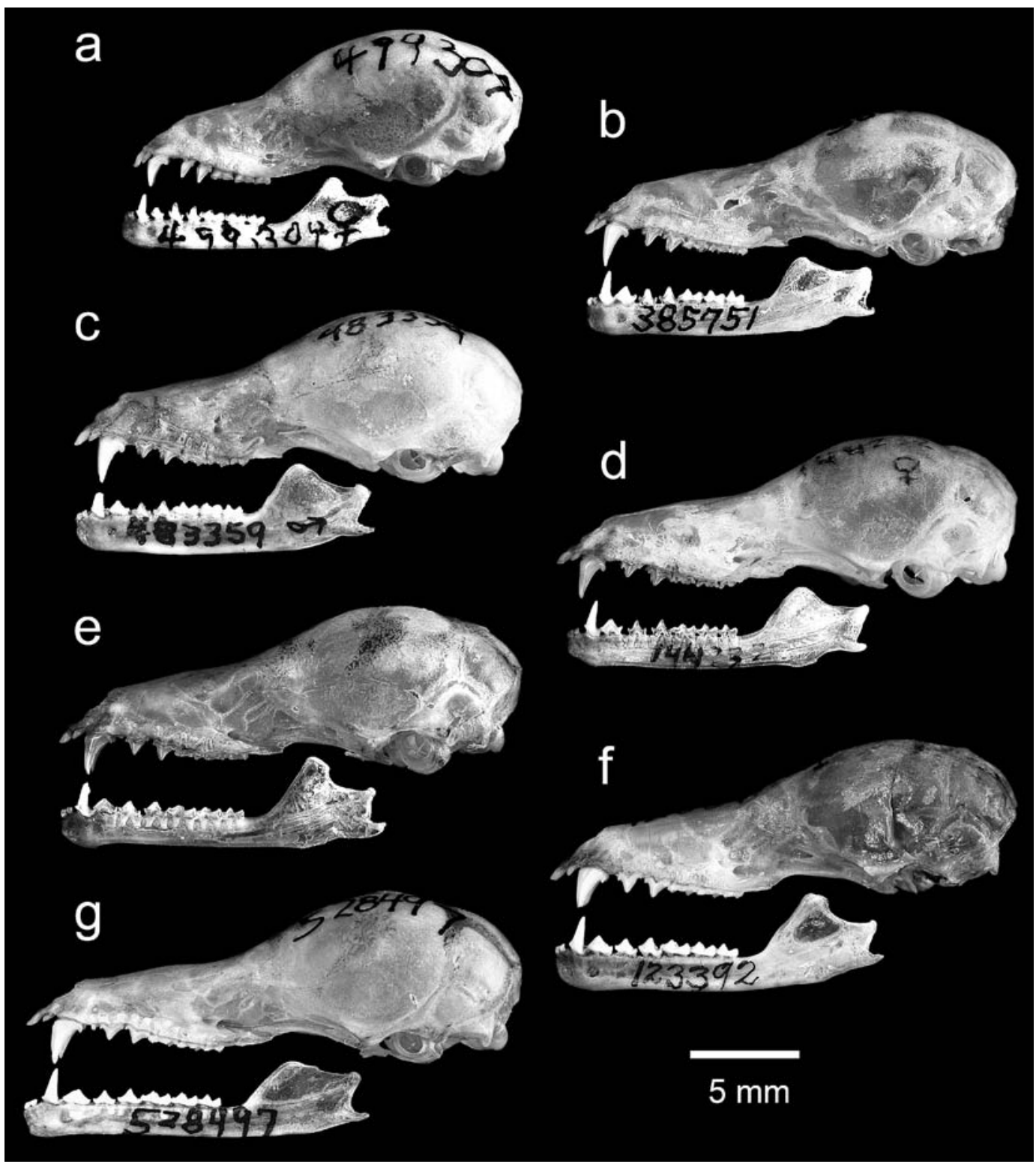

Fig. 4. Lateral view of skulls of (a) Lionycteris spurrelli, (b) Lonchophylla thomasi, (c) L. cadenai, (d) $L$. pattoni, (e) L. dekeyseri, (f) L. mordax, and (g) L. concava. All photographs to same scale.

smooth, lacking lateral projections; posterior margin of infraorbital foramen not projecting beyond lateral outline of rostrum. In lateral view, posterior border of infraorbital foramen above posterior root of $\mathrm{P} 4$ to above anterior root of M1. In palatal view, obvious gap between I1 and I2; lingual cusp of $\mathrm{P} 4$ reduced or absent; upper molars large; postprotocrista of M1 and M2 joins posteriorly with base of metacone, posthypocrista and hypoconal basin absent; transition of posterior palate to postdental palate interrupted by deep midline groove; palate posterior to M3 much greater than half length of M3; posteromedial edge of palate posterior to optic foramen and near anterior end of sphenoidal fissure; mesopterygoid fossa 
VOLUME 119, NUMBER 4

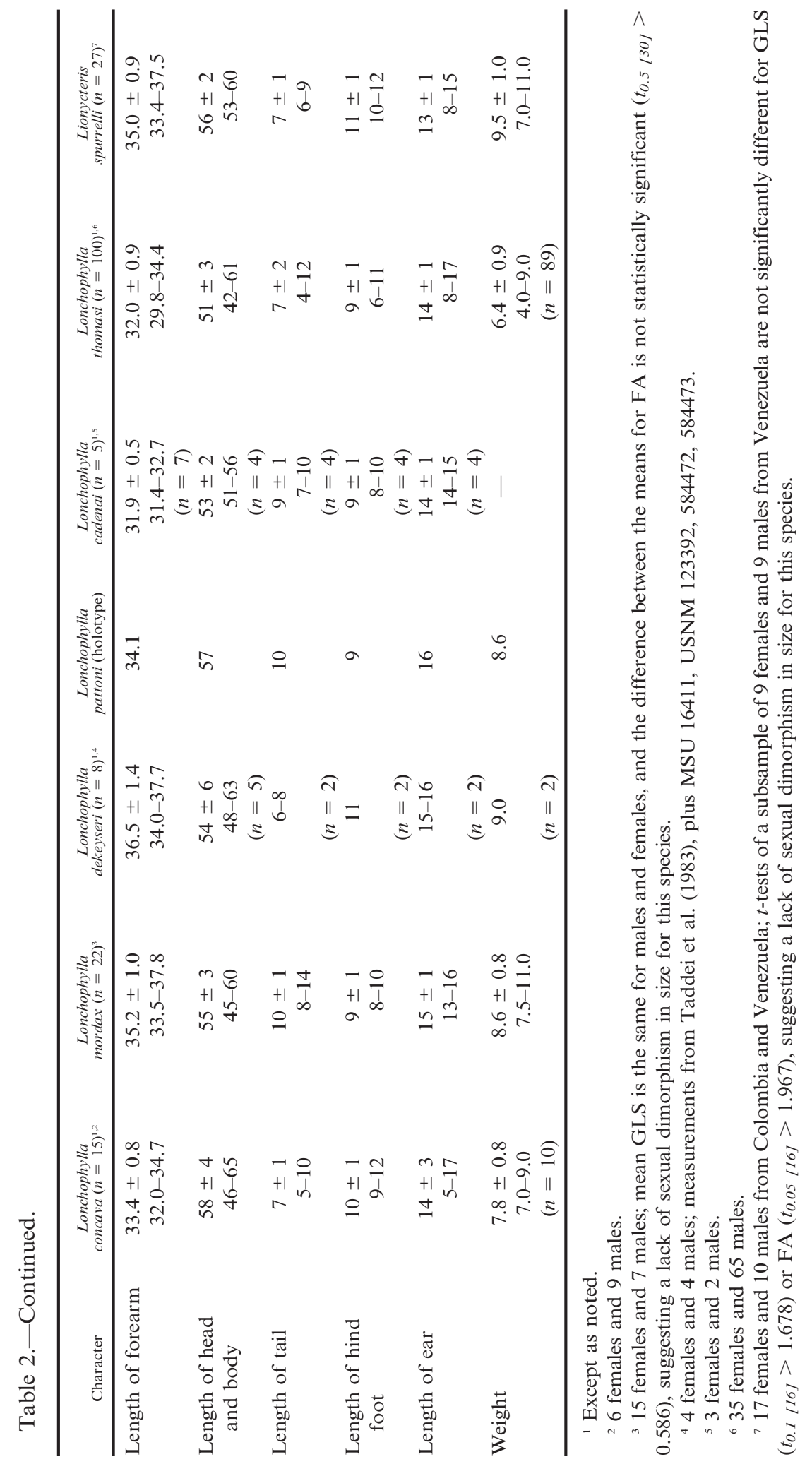


long, open, and U-shaped or W-shaped anteriorly; median projection of palate may extend posteriorly into mesopterygoid fossa; pterygoid processes narrow, uninflated; basisphenoid pits shallow; septum between basisphenoid pits relatively broad. Dentary long and slender; coronoid process low, with broadly rounded apex only slightly above level of articular condyle; upper sigmoid notch shallow; articular process long; p2 massive, bladelike, lacking posterior cusp. In dorsal view, gap between i2 and canine typically much greater than length of i2.

Taxonomic status.-Lonchophylla concava has been treated as a subspecies of $L$. mordax since Handley's (1966:763) study of Panamanian $L$. concava, in which he stated: "the Panamanian subspecies is $L$. $m$. concava Goldman, which is only slightly differentiated from typical $L$. mordax." Recently, however, Albuja \& Gardner (2005) detailed a number of distinctive differences between the two taxa and recognized them as distinct species. The two Bolivian specimens they reported as $L$. mordax, we have reidentified as $L$. dekeyseri. With our reidentification of these specimens, L. mordax is now known only from northeastern Brazil. Despite this, we concur with the conclusions of Albuja and Gardner regarding the taxonomic status of $L$. concava.

Because of the historical confusion surrounding the identification and status of these three species, we carried out a PCA using 10 variables from $16 \mathrm{~L}$. concava, $4 \mathrm{~L}$. dekeyseri, and $23 L$. mordax. A plot of factor scores on the first two factor axes (Fig. 5) is indicative of the distinctiveness of $L$. concava and $L$. mordax. Although the two species overlap greatly in overall size (PC 1-Table 3), they differentiate along $\mathrm{PC}$ 2, which contrasts the larger $\mathrm{PL}$ and $\mathrm{BB}$ of $L$. concava with its lesser HCP and FA. The combined effects of the two axes separate the two species completely. Lonchophylla dekeyseri and L. mordax are less clearly separated in this plot. In a second analysis (not shown) using only these two species, the two separated without overlap. Lonchophylla dekeyseri tends to be smaller cranially but has a proportionally longer forearm than L. mordax (Table 2).

Lonchophylla dekeyseri Taddei, Vizotto, \& Sazima, 1983

Dekeyser's Nectar Bat Figs. 2e, 3e, 4e, 11c

Type locality.- "Parque Nacional de Brasília, Distrito Federal, Brasil, cerca de $8 \mathrm{~km}$ ao Norte do centro da cidade (aprox. $15^{\circ} 48^{\prime} \mathrm{S}, 47^{\circ} 47^{\prime} \mathrm{W}$, ca. $1100 \mathrm{~m}$ de alt.)" (Taddei et al. 1983:626).

Distribution.-Distrito Federal, Minas Gerais, and Piauí in eastern Brazil (Taddei et al. 1983), and Santa Cruz in Bolivia; elevational distribution to at least ca. $1100 \mathrm{~m}$.

Description.-Lonchophylla dekeyseri is a medium-sized species based on GLS and $\mathrm{HB}$, but it has a relatively long FA (Table 2). Dorsal pelage of two Bolivian specimens 4-7 $\mathrm{mm}$ in length, distinctly bicolored or indistinctly tricolored with pale (Light Drab) bases (ca. 60\% of length); distal portions Dresden Brown on lower back to Prout's Brown near head, sometimes with pale tips; venter obviously paler than dorsum, Drab Gray on belly to Light Drab near chest. A faded specimen from Brazil (USNM 238008) has bicolored to tricolored dorsum with paler bases Light OchraceousBuff, distally Cinnamon-Brown, some hairs with pale tips; venter Pale Ochraceous-Salmon. Anterior edge of upper canine convexly rounded. In dorsal view, rostrum long and moderately broad; rostrum inflated above M1s, lateral outlines convex; postorbital region moderately inflated, typically lacking small lateral projections; posterior margin of infraorbital foramen does not project beyond lateral outline of rostrum. In lateral view, posterior border of infra- 


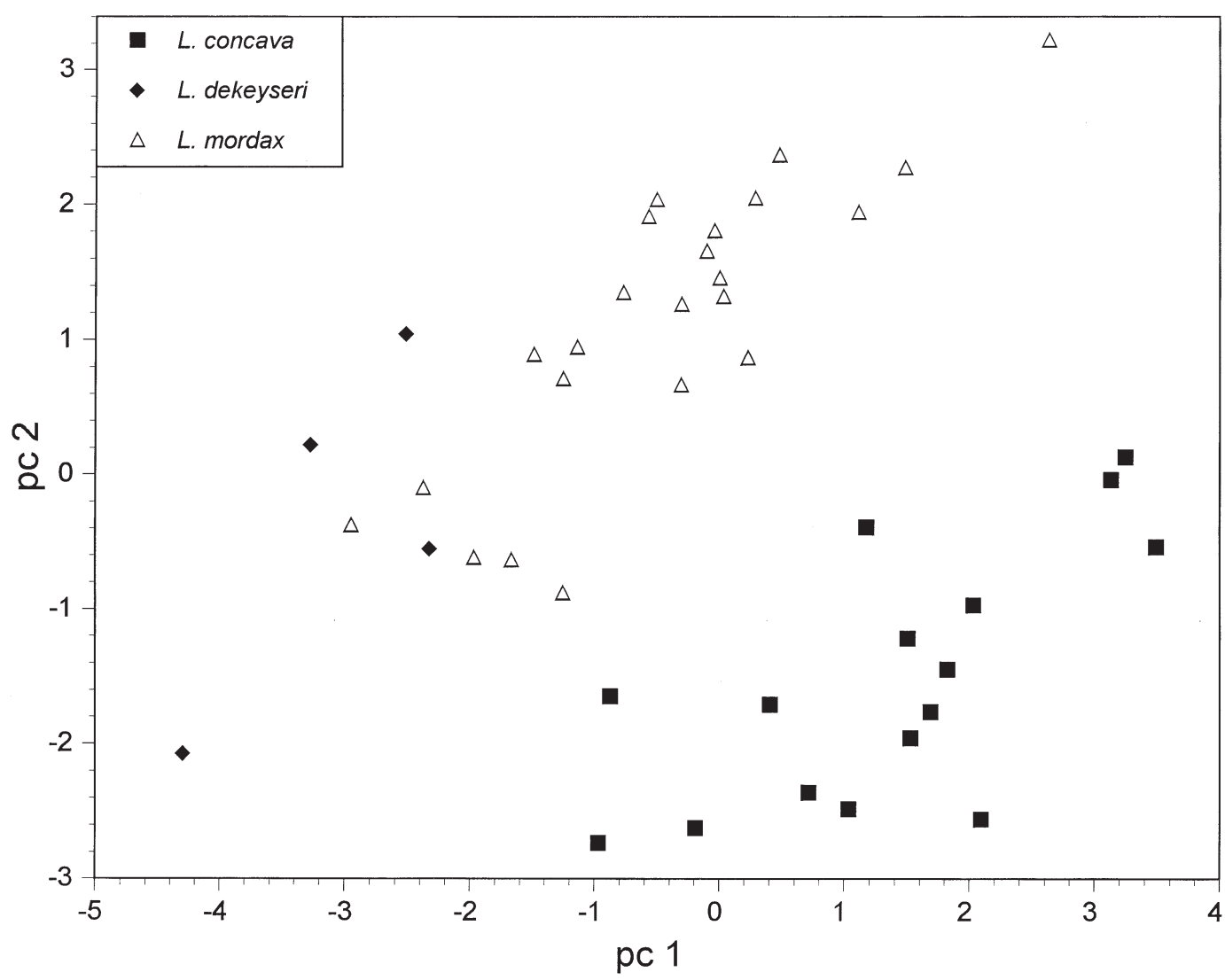

Fig. 5. Plot of scores on first and second axes from PCA of 10 variables from $16 \mathrm{~L}$. concava, $3 \mathrm{~L}$. dekeyseri, and 23 L. mordax (Table 3).

Table 3.-Factor loadings for the first two axes from PCA of 10 variables from $16 \mathrm{~L}$. concava, $3 \mathrm{~L}$. dekeyseri, and 23 L. mordax (Fig. 5).

\begin{tabular}{lcc}
\hline \multirow{2}{*}{ Variable } & \multicolumn{2}{c}{ Correlations } \\
\cline { 2 - 3 } GLS & PC 1 & PC 2 \\
PL & 0.382 & 0.048 \\
PO & 0.275 & -0.398 \\
ZB & 0.309 & -0.035 \\
BB & 0.350 & 0.227 \\
MB & 0.361 & -0.322 \\
TR & 0.416 & 0.138 \\
MM & 0.334 & 0.295 \\
HCP & 0.376 & 0.064 \\
FA & -0.037 & 0.543 \\
Eigenvalue & -0.041 & 0.527 \\
Proportion of & 3.8618 & 2.6087 \\
$\quad$ variation & $38.6 \%$ & $26.1 \%$ \\
\hline
\end{tabular}

orbital foramen generally above posterior root of P4. In palatal view, little or no gap between I1 and I2; P4 typically possesses obvious, rooted lingual cusp; molars large; postprotocrista of $\mathrm{M} 1$ and $\mathrm{M} 2$ joins posteriorly with base of metacone, posthypocrista reduced, vestige of hypoconal basin may be present; transition of posterior palate to postdental palate not interrupted by deep midline groove; palate posterior to M3 less than half length of M3; posteromedial edge of palate just anterior to, or at, posterior border of optic foramen; mesopterygoid fossa long, open, and U-shaped or Wshaped anteriorly; median projection of palate typically extends posteriorly into mesopterygoid fossa; pterygoid processes narrow, uninflated; basisphenoid pits 
deep; septum between basisphenoid pits narrow and steep-sided, forming a rounded ridge. Dentary moderately long and deep, coronoid process high (well above level of articular condyle), with narrowly rounded or pointed apex; deep sigmoid notch; articular process short; $\mathrm{p} 2$ massive, but with small posterior cusp. In dorsal view, gap between i2 and canine typically narrower than length of i2.

\section{Lonchophylla mordax Thomas, 1903 Brazilian Nectar Bat Figs. 2f, 3f, 4f}

Type locality.- "Lamarão, N.W. of Bahia. Alt. 300 m" (Thomas 1903:460), Brazil.

Distribution.-Occurs up to at least ca. $550 \mathrm{~m}$ in northeastern Brazil (Taddei et al. 1983).

Description.-Lonchophylla mordax is a relatively large species based on GLS, $\mathrm{HB}$, and FA (Table 2). Dorsal fur on faded paratype (USNM 123392) 4-6 mm long, distinctly bicolored with paler bases (ca. $80 \%$ of length) Pale Ochraceous-Buff, darker tips Cinnamon-Brown; distinctly paler venter is Pale Ochraceous-Buff. The darker tips of the dorsal hairs from a series of specimens collected more recently (February-September 1977) vary from Ochraceous-Tawny or Buckthorn Brown on paler specimens to Sepia on darker specimens; bases of dorsal hairs are white; ventral pelage varies from Pale Ochraceous-Salmon or Pale Pinkish Cinnamon to Light Buff. Anterior edge of upper canine convexly rounded. In dorsal view, rostrum long and moderately broad; rostrum inflated above M1s, lateral outlines convex; postorbital region moderately inflated, lacking lateral projections; posterior margin of infraorbital foramen not projecting beyond lateral outline of rostrum. In lateral view, posterior border of infraorbital foramen is between anterior and posterior roots of $\mathrm{P} 4$ to above posterior root of $\mathrm{P} 4$. In palatal view, little or no gap between I1 and I2; P4 typically possesses obvious, rooted lingual cusp; upper molars large; postprotocrista of M1 and M2 joins posteriorly with base of metacone, posthypocrista reduced, vestige of hypoconal basin may be present; transition of posterior palate to postdental palate not interrupted by deep midline groove; palate posterior to M3 less than half length of M3; posteromedial edge of palate just anterior to, or at, posterior border of optic foramen; mesopterygoid fossa long, open, and U-shaped or Wshaped anteriorly; median projection of palate typically extends posteriorly into mesopterygoid fossa; pterygoid processes narrow, uninflated; basisphenoid pits deep; septum between basisphenoid pits narrow and steep-sided, forming rounded ridge. Dentary moderately long and deep, coronoid process high (well above level of articular condyle), with narrowly rounded apex; deep sigmoid notch; articular process short; p2 massive, but with small posterior cusp. In dorsal view, gap between i2 and canine typically equal to or narrower than length of i2.

Remarks.-Our sample of 15 female and 7 male L. mordax exhibited no apparent sexual dimorphism in size (Table 2 ; footnote 3 ).

Lonchophylla thomasi J. A. Allen, 1904

Thomas's Nectar Bat

Figs. 2b, 3b, 4b, 9b, d

Type locality.- "Cuidad [sic] Bolivar, Venezuela" (J. A. Allen 1904:230) $\left[8^{\circ} 08^{\prime} \mathrm{N}, 63^{\circ} 33^{\prime} \mathrm{W}\right.$; Bolívar State, ca. $100 \mathrm{~m}$, on right bank of Río Orinoco, ca. $300 \mathrm{~m}$ from its mouth-(Paynter 1982)].

Distribution.-The mostly widely distributed species of Lonchophylla, L. thomasi occurs primarily in the northern Amazon and Orinoco basins east of the Andes Cordillera. This bat is known from extreme eastern Panama south to the Amazonian regions of Colombia, Ecuador, Peru, and Bolivia, Venezuela south of the Río Orinoco, the Guianas, and 


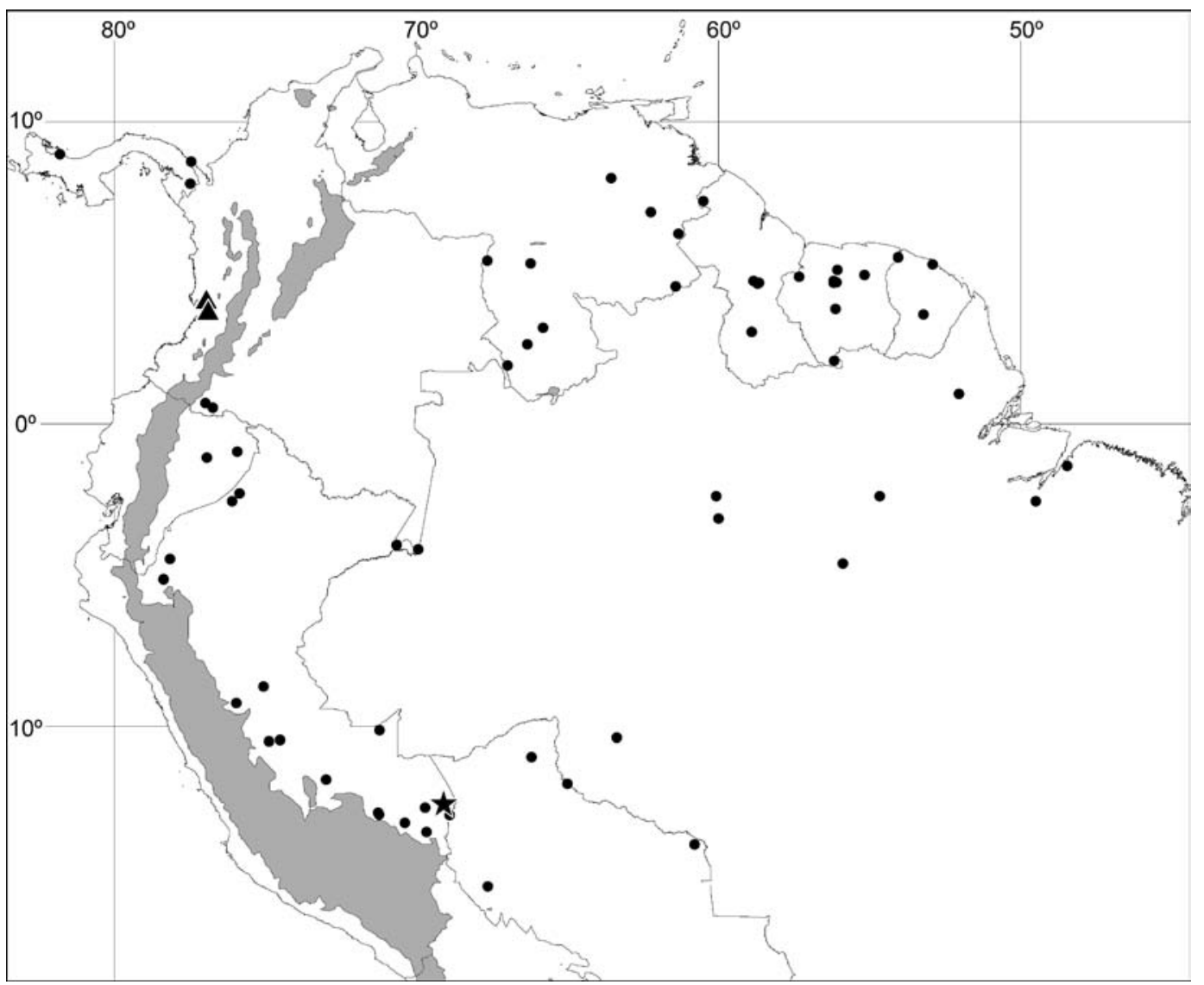

Fig. 6. Map of southern Central America and northwestern South America illustrating provenances of specimens of Lonchophylla thomasi (filled circles), L. pattoni (star), and L. cadenai (filled triangles) used in this paper. Shaded areas $>2000 \mathrm{~m}$ in elevation.

Amazonian Brazil (Fig. 6). In Peru, it has been found from 200 to 1350 m elevation (Pacheco et al. 1993, Patterson et al. 1996, Linares 1998).

Description.-Lonchophylla thomasi is the smallest species in the genus based on mean GLS, HB, and FA (Table 2). Dorsal pelage 5-7 $\mathrm{mm}$ long, distinctly bicolored with paler bases $(75-80 \%$ of length) typically about Pale Pinkish Buff, but may approach Pale Ecru Drab, tips about Dresden Brown to Clove Brown (specimens from Bolivia have darker tipped hairs and appear darker overall; those from Guyana have darker tips and paler bases, the latter closer to white); venter somewhat paler than dorsum, generally darkening from abdomen to neck, hairs indistinctly bicolored, appearing Sayal Brown to Mummy Brown overall (specimens from Guyana have more distinctly bicolored ventral pelage); genal vibrissae absent; central rib of noseleaf extends to tip. Anterior edge of upper canine flat, possibly by wear against lower canine. In dorsal view, rostrum short and broad; rostrum only slightly inflated above M1s, lateral outlines gently convex; postorbital region inflated, typically lacking lateral projections; posterior margin of infraorbital foramen typically projects beyond lateral outline of rostrum. In lateral view, posterior border of infraorbital foramen 
typically is above anterior root of $\mathrm{P} 4$ or between anterior and posterior roots of P4, but may be between P3 and P4. In palatal view, obvious gap between I1 and I2; P4 typically possesses obvious, rooted lingual cusp; molars typically smaller than in $L$. concava, $L$. dekeyseri, and $L$. mordax; postprotocrista of M1 and M2 joins posteriorly with base of metacone, posthypocrista and hypoconal basin absent; transition of posterior palate to postdental palate not interrupted by deep midline groove (as in L. concava); palate posterior to M3 greater than half length of M3; posteromedial edge of palate well posterior to optic foramen and near middle of sphenoidal fissure; mesopterygoid fossa short and acutely V-shaped anteriorly; anterior border of mesopterygoid fossa smooth, lacking median projection of palate; pterygoid processes inflated, broadly rounded ventrally; basisphenoid pits deep; septum separating basisphenoid pits narrow and steep-sided, forming sharp ridge. Dentary short and deep; coronoid process low (slightly above level of articular condyle), broadly rounded or pointed; articular process short; p2 with well-defined posterior cusp similar to that of $\mathrm{p} 3$. In dorsal view, gap between i2 and canine typically narrower than length of i2.

Geographic variation.-Lonchophylla thomasi exhibits little geographic variation in multivariate space. In a plot of scores of PC 1 (overall size-Table 4) and PC 2 (cranial length vs. width) from a PCA of L. thomasi, there is considerable overlap among samples from throughout the species's geographic range (Fig. 7). The only exceptions we found are individuals from Panama. Although the Panamanian sample tends to overlap considerably in multivariate space with most other large geographic samples, it is also more constrained morphometrically. The Panamanian bats average slightly larger in many cranial and external variables (PC 1; Table 5), and they have longer and narrower crania (PC 2). They also tend to have relatively short forearms and higher coronoid processes (PC 3-not plotted).

Sexual dimorphism.-Differences between sexes, at the level at which we can accurately measure them in our samples of $L$. thomasi, represent tendencies rather than obvious distinctions. Among individual variables, for example, mean GLS is slightly larger in females than in males in the subsamples of $L$. thomasi from Brazil, Panama, and Peru, but not in the whole sample from throughout the species's range (Table 5), and none of these differences is statistically significant using a Bonferroni correction for simultaneous testing among three variables (GLS, FA, HCP; $\alpha_{\beta}=\alpha / 3$ $=0.01667$ ). Similarly, FA is slightly longer in females than in males in all four groupings, but the difference is statistically significant only for the subsample from Peru $\left(t_{s}=3.657>t_{0.001}[30]\right)$ and the whole sample $\left(t_{s}=2.753>\right.$ $t_{0.01}[98]$ ] $)$ HCP tends to be higher in males than in females. This difference is not statistically different for the entire sample of $L$. thomasi $\left(t_{s}=2.385<\right.$ $\left.t_{0.02[98]}\right)$, but it is significant within both of the larger subsamples from Brazil $\left(t_{s}=\right.$ $\left.3.395>t_{0.01}[14]\right)$ and Peru $\left(t_{s}=2.958>\right.$ $\left.t_{0.01[30]}\right)$.

In plots of scores from a PCA of $L$. thomasi from throughout its geographic distribution, males and females were not differentiated along either PC 1 or PC 2 (plots not shown). In a plot of PC 3 (primarily a contrast between FA and HCP_-Table 4) and PC 4 (PO), there is broad overlap between the sexes in the ranges of values, but the areas of highest concentration for males and females are different (Fig. 8). Females tend to have higher scores on PC 3 and lower scores on PC 4, reflecting weak tendencies to have longer forearms, lower coronoid processes, and broader postorbital regions (Table 5). 
Table 4.-Factor loadings for the first four axes from PCA of 10 variables from 41 female, 71 male, and 3 sex unknown L. thomasi for studies of geographic variation (Fig. 7) and sexual dimorphism (Fig. 8).

\begin{tabular}{lrrrr}
\hline & \multicolumn{4}{c}{ Correlations } \\
\cline { 2 - 5 } \multicolumn{1}{c}{ Variable } & PC 1 & PC 2 & \multicolumn{1}{c}{ PC 3 } & PC 4 \\
\hline GLS & -0.445 & -0.197 & 0.002 & -0.179 \\
PL & -0.342 & -0.458 & -0.057 & -0.147 \\
PO & -0.148 & 0.404 & 0.023 & -0.802 \\
ZB & -0.362 & 0.206 & -0.155 & 0.336 \\
BB & -0.290 & 0.462 & -0.076 & 0.141 \\
MB & -0.375 & 0.296 & -0.176 & -0.018 \\
TR & -0.299 & -0.363 & 0.308 & -0.214 \\
MM & -0.271 & 0.210 & 0.296 & 0.255 \\
HCP & -0.291 & -0.261 & -0.585 & 0.126 \\
FA & -0.245 & -0.030 & 0.641 & 0.209 \\
Eigenvalue & 3.8747 & 1.5997 & 1.0441 & 0.8899 \\
Proportion of & $38.7 \%$ & $16.0 \%$ & $10.4 \%$ & $8.9 \%$ \\
$\quad$ variation & \multicolumn{5}{c}{} \\
\hline
\end{tabular}

Lonchophylla pattoni, new species Patton's Nectar Bat

Figs. 2d, 3d, 4d, 9a, 11d

Lonchophylla thomasi: Woodman et al., 1991:7 (in part); Voss and Emmons, 1996:110 (in part).

Holotype.-Dried skin, skull, body skeleton, and frozen tissues of a nulliparous adult female, University of Kansas Natural History Museum (KU) number 144232, obtained 10 Jun 1989 by Neal Woodman (original number NW 460). Condition generally excellent, however, distal ends of I1s broken off; right dentary broken; left auditory bulla separated from cranium. This specimen will be transferred to Museo de Historia Natural,

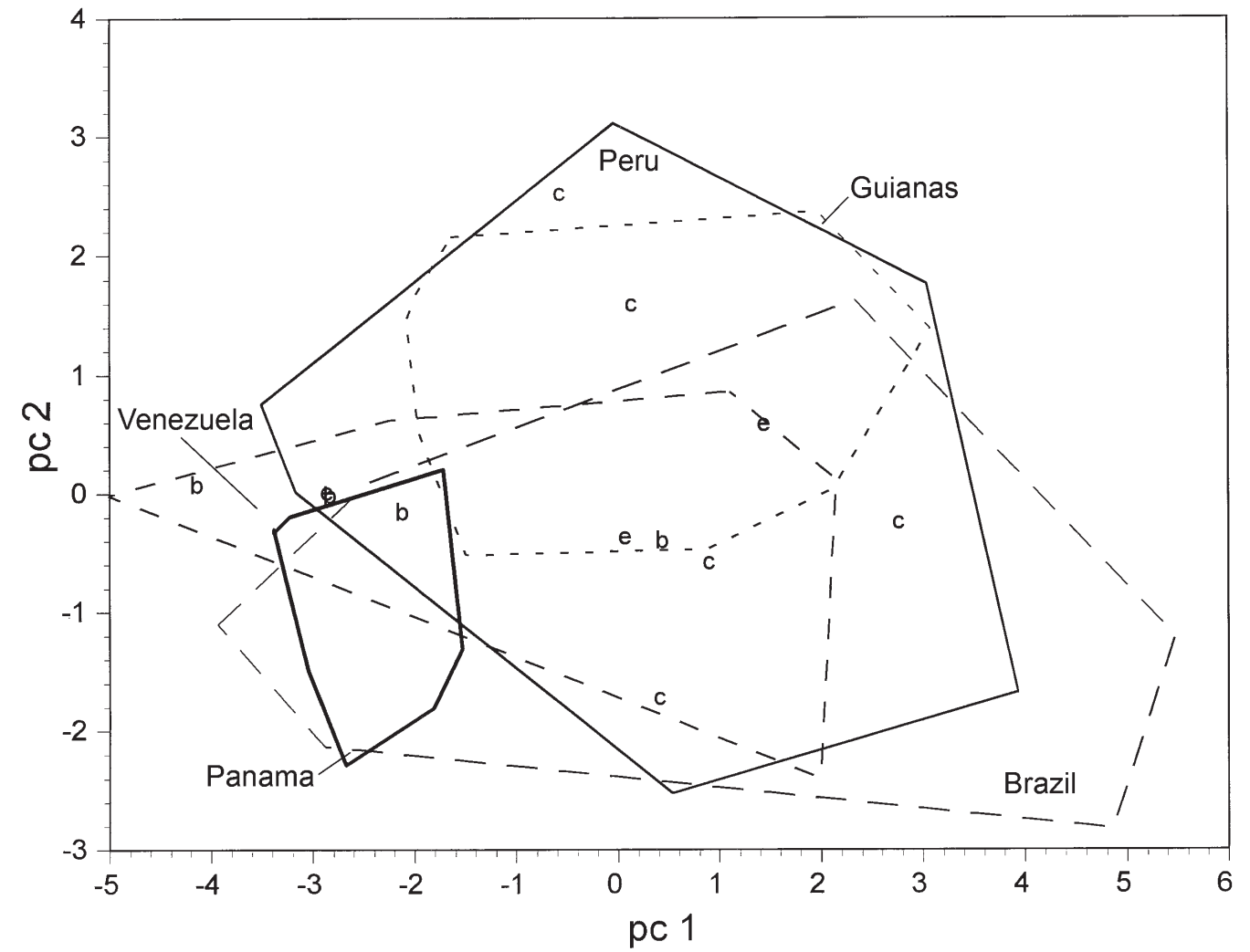

Fig. 7. Plot of scores on first two axes from PCA of 10 variables from 115 L. thomasi (Table 4). Polygons connect outlying individuals from each of five countries or regions with largest samples. Individuals from Bolivia (b), Colombia (c), and Ecuador (e) represented by lower case letters on graph. 
Universidad Nacional Mayor de San Marcos, Lima, Peru.

Type locality.- Reserva Cusco Amazónico (ca. $12^{\circ} 33^{\prime} \mathrm{S}, 69^{\circ} 03^{\prime} \mathrm{W}$ ), $200 \mathrm{~m}$ elevation; north bank of the Río Madre de Dios; $14 \mathrm{~km}$ east of Puerto Maldonado; Tambopata Province; Madre de Dios Department; southeastern Peru.

Etymology.-We name this species in honor of Dr. James L. Patton, University of California, Berkeley, in recognition of his many contributions to the study of Neotropical mammals. His research efforts, enthusiasm, and generosity have greatly influenced our understanding of the world's mammals and mammalian evolution.

Distribution.-Known only from the type locality in the Amazon lowlands of southeastern Peru (Fig. 6).

Diagnosis.-A small Lonchophylla most easily distinguished from L. bokermanni, $L$. chocoana, L. handleyi, L. hesperia, $L$. orcesi, and $L$. robusta by its smaller cranial size (GLS $<24.0 \mathrm{~mm}$ ). From other small Lonchophylla, L. pattoni can be distinguished by its long, pale, reddishbrown, distinctly bicolored dorsal pelage with pale bases to the hairs; lack of lateral projections in postorbital region; anterior position of posterior border of infraorbital foramen (unlike L. concava, L. dekeyseri, L. mordax); obvious, rooted lingual cusp on P4 (unlike L. concava); lack of deep groove along midline of posterior palate (unlike L. concava); short, acute, $\mathrm{V}$-shaped mesopterygoid fossa lacking a median projection of palate (unlike $L$. concava, L. dekeyseri, L. mordax); broadly inflated pterygoid processes (unlike $L$. concava, L. dekeyseri, L. mordax); deep basisphenoid pits separated by narrow, steep-sided septum (unlike L. concava); long, slender dentary with low, rounded coronoid process and long articular process (unlike L. dekeyseri, L. mordax); posterior cusp on p2 (unlike L. concava); gap between i2 and canine about as wide as length of i2 (unlike L. concava). 


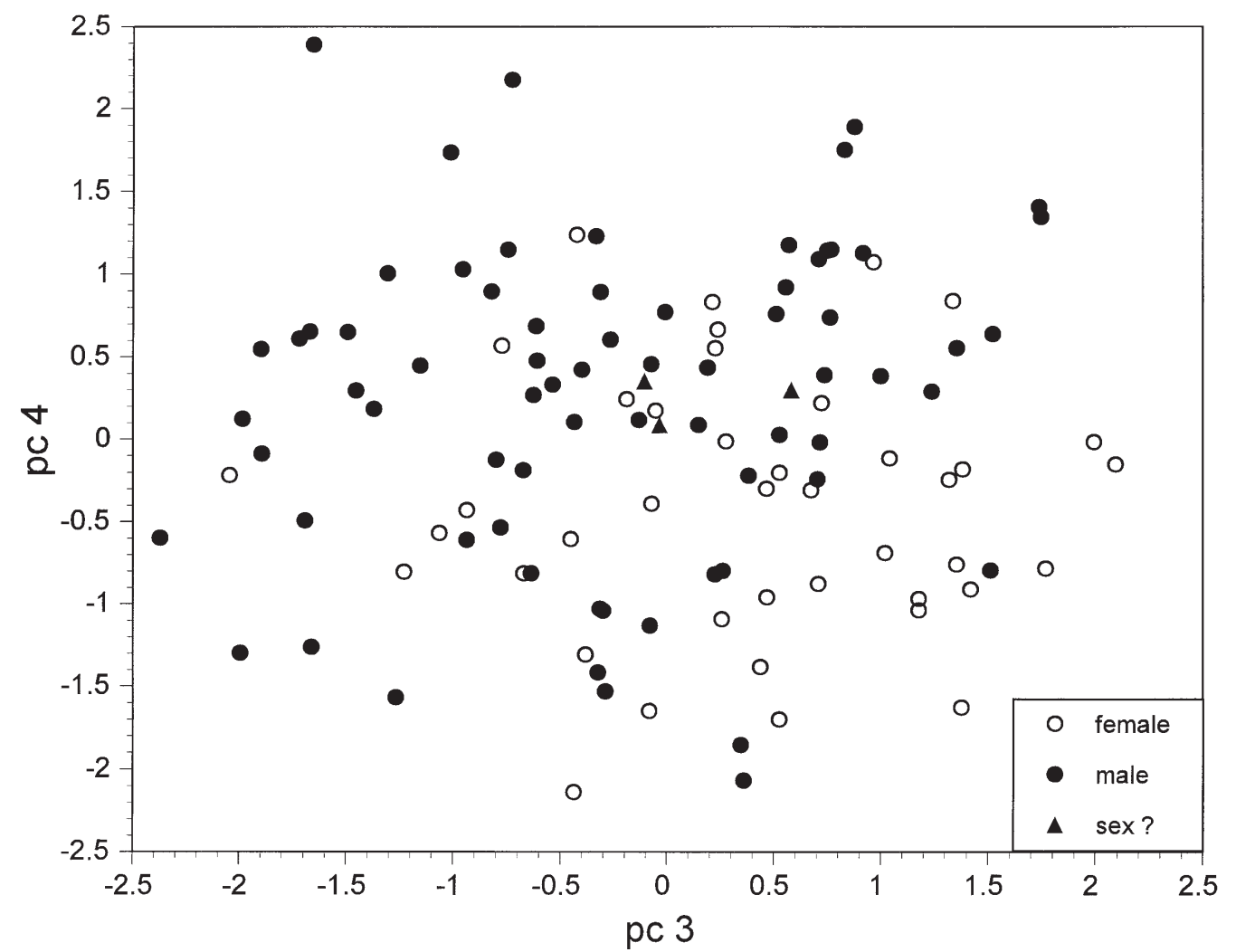

Fig. 8. Plot of scores on third and fourth axes from PCA of 10 variables from 41 female and 71 male $L$. thomasi (Table 4).

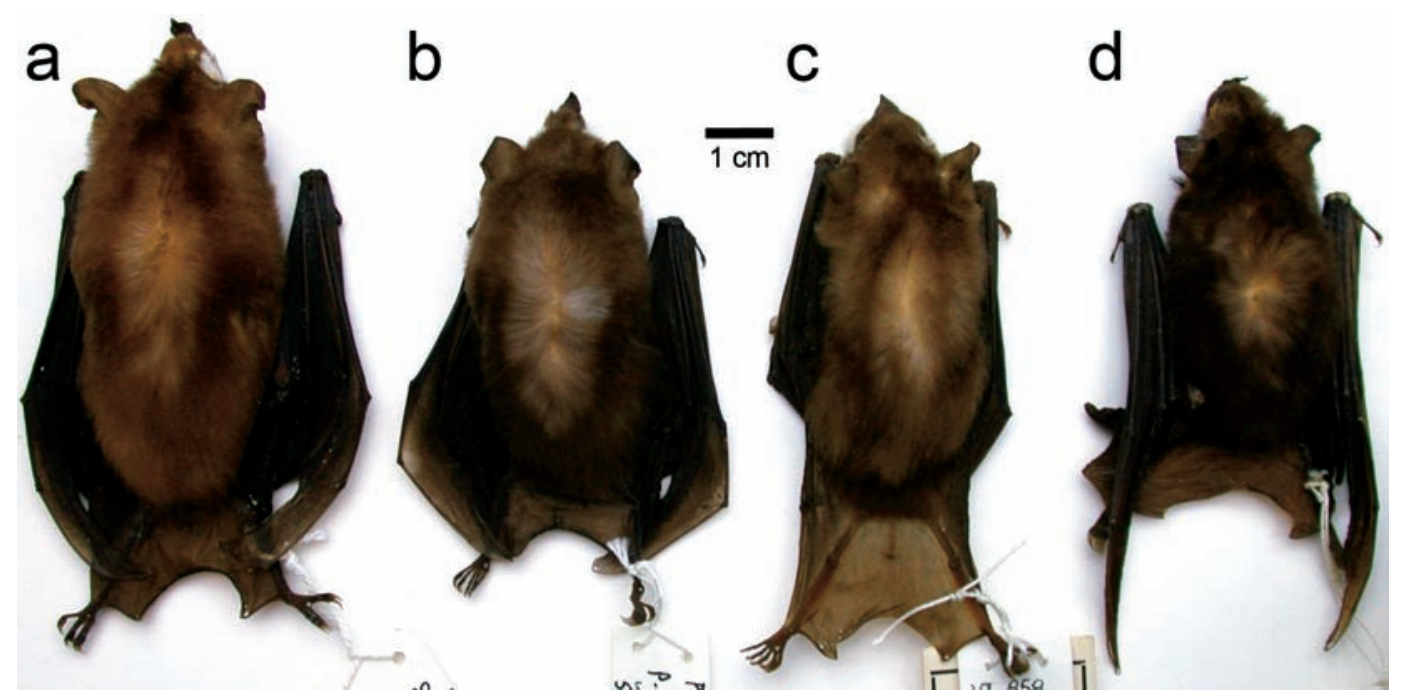

Fig. 9. Dried skins of (a) L. pattoni (KU 144232, FA = 34.1); (b) L. thomasi from Madre de Dios, Peru (UMMZ 160710, FA = 30.7); (c) L. cadenai (USNM 483359, FA = 31.4); and (d) L. thomasi from Bolivar, Venezuela (USNM 385753, FA $=32.4$ ). 
Description.-Lonchophylla pattoni is a medium-sized species based on GLS and FA, but it has a relatively long HB (Table 2). The reddish brown pelage of $L$. pattoni is closest to that of $L$. robusta (although bases of hairs in the former are proportionally longer and paler), but in most cranial characters, $L$. pattoni is most similar to $L$. thomasi (Fig. 9). Dorsal hairs 6-7 mm long, distinctly bicolored with paler basal two-thirds or so of dorsal hairs tending toward Pale Vinaceous Fawn, distal segment Verona Brown to Snuff Brown, some hairs with slightly paler tips; venter somewhat paler than dorsum, proximal half of hairs pale, distal segment approaches Sayal Brown to Snuff Brown. Genal vibrissae absent; weakly developed central rib of noseleaf extends to tip. Anterior edge of upper canine flat. In dorsal view, rostrum narrow, only slightly inflated above M1s, with gently convex lateral margins; postorbital region inflated, lacking lateral projections; posterior margin of infraorbital foramen projects laterally beyond lateral outline of rostrum. In lateral view, posterior border of infraorbital foramen above area between P3 and P4. In palatal view, obvious gaps between I1 and I2; P4 typically possesses obvious, rooted lingual cusp; molars small; postprotocrista of M1 and M2 joins posteriorly with base of metacone; posthypocrista and hypoconal basin absent; protoconal basin reduced; transition of posterior palate to postdental palate not interrupted by deep midline groove; palate posterior to M3 much greater than half length of M3; posteromedial edge of palate well posterior to optic foramen and near middle of sphenoidal fissure; mesopterygoid fossa short and has an acutely V-shaped anterior margin; anterior border of mesopterygoid fossa smooth, lacking median projection of palate; pterygoid processes inflated, broadly rounded ventrally; basisphenoid pits deep; septum between basisphenoid pits narrow and steep-sided, forming sharp ridge. Dentary long and slender; coronoid process low (slightly above level of articular condyle) and broadly rounded; articular process long; p2 with welldefined posterior cusp similar to that of p3. In dorsal view, gap between i2 and canine about as wide as length of i2.

Comparisons.-From Lonchophylla bokermanni, L. chocoana, L. handleyi, L. hesperia, L. orcesi, L. robusta, and Platalina genovensium, $L$. pattoni is easily distinguished by its much smaller size $($ GLS $<24.0 ;$ FA $<37.0 ;$ HB $<60$ Table 1).

Lionycteris spurrelli: Lonchophylla pattoni is distinctly larger in all linear dimensions of cranium and has long, silky, clearly bicolored dorsal pelage with pale hair bases; much longer, narrower rostrum with more nearly parallel lateral margins; more anteriorly located posterior border of infraorbital foramen that projects beyond lateral outline of rostrum; elongated and laterally compressed P3 and $\mathrm{P} 4$; lingual cusp lacking on $\mathrm{P} 3$; smaller, more triangular (in outline) upper molars; less highly domed midline of central palate; strongly convex posterolateral borders of palate; short, acutely Vshaped mesopterygoid fossa lacking median projection of palate; inflated pterygoid processes; deep basisphenoid pits separated by narrow, steep-sided septum; much longer, more slender dentary; lower, broader coronoid process and shallower sigmoid notch; longer articular process; elongated, laterally compressed $\mathrm{p} 3$ and $\mathrm{p} 4$ with lower central cusp centered between roots; larger gap between i2 and canine.

Lonchophylla concava: Lonchophylla pattoni has paler, reddish-brown dorsal pelage that has paler (reddish rather than grayish) bases to hairs; more anteriorly located posterior border of infraorbital foramen that projects beyond lateral outline of rostrum; relatively shorter and broader palate; well-developed, rooted lingual cusp on P4; smaller molars having reduced protoconal basin; deep groove 
lacking from midline of posterior palate; short, acutely V-shaped mesopterygoid fossa lacking median projection of palate; inflated pterygoid processes; deep basisphenoid pits separated by narrow, steepsided septum; slightly higher and not as broadly rounded coronoid process; welldefined posterior cusp on $\mathrm{p} 2$; smaller gap between $\mathrm{i} 2$ and canine.

Lonchophylla dekeyseri: Lonchophylla pattoni has paler, reddish-brown dorsal pelage; shorter, narrower, more nearly parallel-sided rostrum; more anteriorly located posterior border of infraorbital foramen that projects beyond lateral outline of rostrum; obvious gaps between I1 and I2; smaller upper molars with reduced protoconal basin; short, acutely Vshaped mesopterygoid fossa lacking median projection of palate; inflated pterygoid processes; much longer and more slender dentary; lower, more broadly rounded coronoid process; shallower sigmoid notch; longer articular process; larger spaces between lower premolars.

Lonchophylla mordax: Lonchophylla pattoni has longer, paler, reddish-brown dorsal pelage; shorter, narrower, more nearly parallel-sided rostrum; more anteriorly located posterior border of infraorbital foramen that projects beyond lateral outline of rostrum; obvious gaps between I1 and I2; smaller upper molars with reduced protoconal basin; short, acutely V-shaped mesopterygoid fossa lacking median projection of palate; inflated pterygoid processes; much longer and more slender dentary; lower and more broadly rounded coronoid process and shallower sigmoid notch; longer articular process; larger spaces between lower premolars.

Lonchophylla thomasi: Lonchophylla pattoni has paler, reddish-brown dorsal pelage; longer cranium (particularly GLS and $\mathrm{CBL}$ ), although similar in cranial breadth, resulting in a relatively long, narrow skull; longer, narrower rostrum; reduced protoconal basin on M1 and M2; much longer and more slender dentary; longer articular process; larger spaces between lower premolars.

Multivariate analysis.-We compared the holotype of Lonchophylla pattoni with 15 female and 22 male $L$. thomasi from Peru using a PCA of 10 measurements. A plot of factor scores on the first two factor axes (Fig. 10) shows that the holotype of $L$. pattoni is distinct from all specimens of Peruvian L. thomasi, being larger overall (PC 1-Table 6) and having a relatively longer cranium (PC 2). Two males approach the holotype in overall size, one from Teniente López, Loreto Dept. (KU 158062), and one from $40 \mathrm{~km}$ east of Quince Mil, Cusco Dept. (LSU 18860). However, these two specimens have shorter skulls, and neither has the reddish external coloration of the holotype nor resembles it in other cranial characters (e.g., slender dentary, long articular process).

Remarks.-Reserva Cusco Amazónico (formerly "Cuzco Amazónico"-Duellman 2005) is a ca. 10,000-ha wildlife reserve along the north bank of the Río Madre de Dios, $14 \mathrm{~km}$ east of Puerto Maldonado, southeastern Peru. The locality on the specimen tag of the holotype originally was recorded as " $15 \mathrm{~km} \mathrm{E}$ Puerto Maldonado." After studying more detailed maps of the region, we now believe that $14 \mathrm{~km}$ east of Puerto Maldonado better reflects the location. The elevation is ca. $200 \mathrm{~m}$, and there is little topographic relief. Vegetation in the reserve is typical of the region and consists primarily of undisturbed, evergreen, lowland tropical forest transitional between Moist Tropical Forest and Dry Tropical Forest (Tosi 1960). As many as 1400 species of angiosperms, including 400 species of trees, may be present in the Cusco Amazónico reserve. The climate of the region is seasonal with a rainy season from October through March and a pronounced dry season from April through September. The mammal fauna at Cusco 


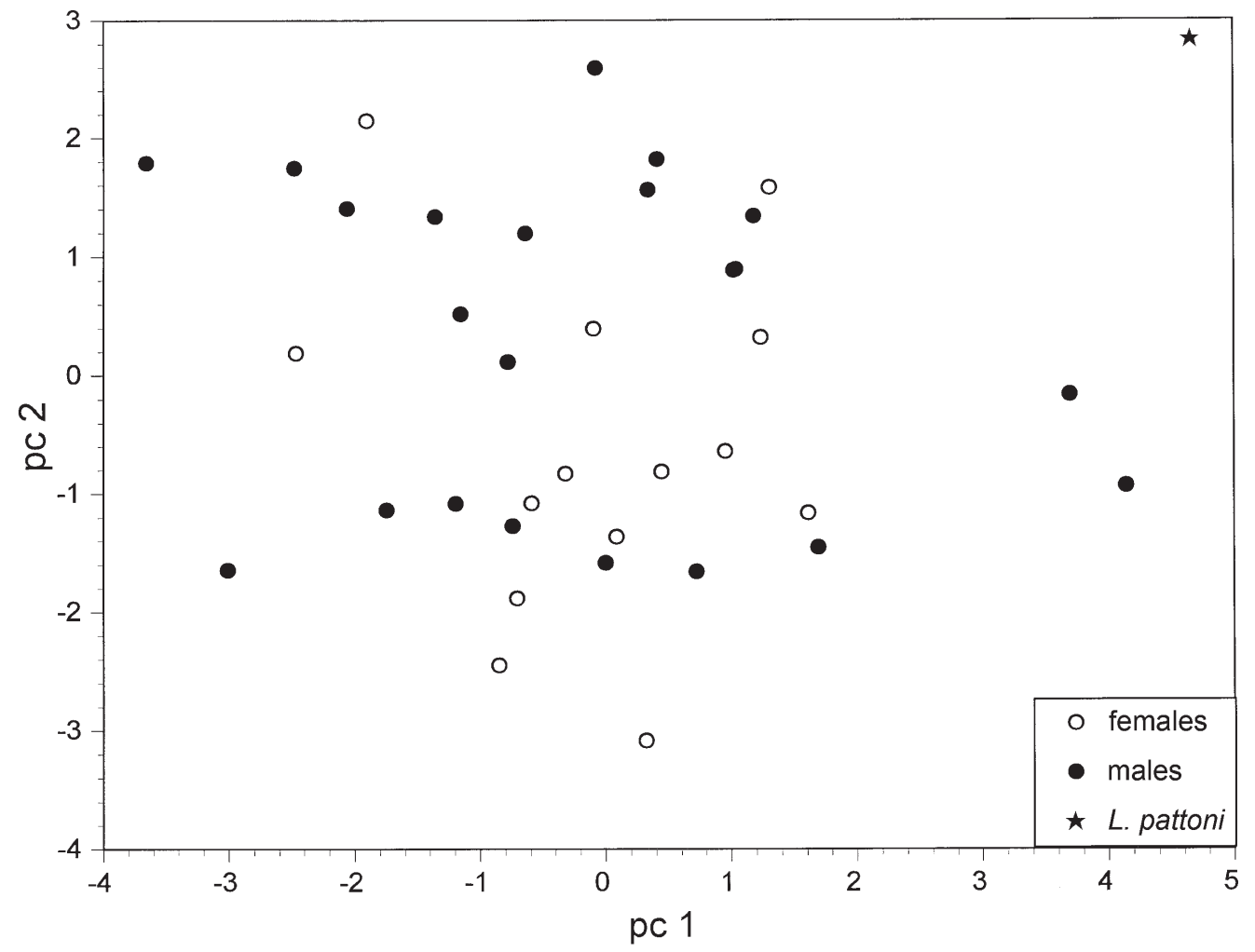

Fig. 10. Plot of scores on first two axes from PCA of the holotype of L. pattoni and 15 female and 22 male L. thomasi from Peru (Table 6).

Table 6.-Factor loadings for the first three axes from PCA of 10 variables from the holotype of $L$. pattoni and 37 Peruvian L. thomasi (Fig. 10). Variables are ordered by correlations on PC 2.

\begin{tabular}{lccr}
\hline \multirow{2}{*}{ Variable } & \multicolumn{3}{c}{ Correlations } \\
\cline { 2 - 4 } & PC 1 & PC 2 & \multicolumn{1}{c}{ PC 3 } \\
\hline PL & 0.289 & 0.446 & -0.048 \\
TR & 0.334 & 0.349 & 0.045 \\
GLS & 0.462 & 0.241 & -0.120 \\
HCP & 0.242 & 0.207 & 0.652 \\
FA & 0.304 & 0.056 & -0.672 \\
MM & 0.321 & -0.195 & 0.115 \\
ZB & 0.376 & -0.249 & 0.232 \\
MB & 0.363 & -0.367 & 0.017 \\
PO & 0.068 & -0.378 & 0.117 \\
BB & 0.245 & -0.444 & -0.154 \\
Eigenvalue & 3.3374 & 2.3100 & 1.1158 \\
Proportion of & $33.4 \%$ & $23.1 \%$ & $11.2 \%$ \\
\multicolumn{1}{c}{ variation } & & & \\
\hline
\end{tabular}

Amazónico is diverse. Woodman et al. (1991) reported 100 species from this locality, including 42 species of bats (not including L. pattoni). Additional details concerning this site, including climate, vegetation, soils, history, and maps, were provided by Duellman \& Koechlin (1991) and Duellman (2005).

Lonchophylla pattoni and L. thomasi are sympatric, and almost certainly syntopic, in southeastern Peru. The single known specimen of $L$. pattoni was captured at about $0530 \mathrm{~h}$ on 10 June 1989 , in a ground-level mist net set that morning for birds in one of the terra firma forest plots at Cusco Amazónico (BIOTROP Study Zone 1, Plot E4; see Duellman \& Koechlin 1991). An adult male L. thomasi was taken during the early morning hours of February 11, 1990, in a mist net set in a clearing between buildings in the 
residential portion of the reserve. In addition, James L. Patton caught an adult male $L$. thomasi at nearby Lago Sandoval on 5 July 1979 (MVZ 157669).

The holotype of L. pattoni was reported by Albuja \& Gardner (2005:448) as representing either "an undescribed species or ... the western representative of $L$. dekeyseri."

Lonchophylla cadenai, new species Cadena's Nectar Bat

Figs. 2c, 3c, 4c, 9c, 11a

Lichonycteris obscura (in part): M. E. Thomas, 1972:157.

Lonchophylla robusta (in part): M. E. Thomas, 1972:157.

Glossophaga soricina (in part): M. E. Thomas, 1972:157-158.

Holotype.-Dried skin and skull of adult male, National Museum of Natural History (USNM 483359), captured 18 Feb 1967 by Andrew A. Arata and Maurice E. Thomas (original number 858).

Type locality.-Twenty-nine $\mathrm{km} \mathrm{SE}$ of Buenaventura, $75 \mathrm{~m}$ elevation; east bank of Río Zabaletas, across from the village of Zabaletas ( $3^{\circ} 44^{\prime} \mathrm{N}, 76^{\circ} 57^{\prime} \mathrm{W}$; Paynter 1997); Valle del Cauca Department; Colombia.

Referred specimens (6).-D Dried skins and skulls of two adult females and an adult male (USNM 483363, 483364, 483365), and fluid-preserved specimens of two adult females (USNM 446481, 446482), all from the type locality; one fluid-preserved specimen with skull removed of adult female (USNM 338726) from Bajo Calima (ca. $4^{\circ} 01^{\prime} \mathrm{N}, 77^{\circ} 00^{\prime} \mathrm{W}$ ), ca. $45 \mathrm{~km}$ by air NNE of Buenaventura, along the Río Calima.

Etymology.-The species name honors Dr. Alberto Cadena, Instituto de Ciencias Naturales, Universidad Nacional de Colombia, Bogotá, whose efforts to establish research resources and involve students have contributed greatly to Colombian science and conservation.
Distribution.-Known only from the central Pacific Coastal Plain, Valle de Cauca, southwestern Colombia (Fig. 6). Albuja (1999:95-96) reported specimens of L. thomasi from La Chiquita and Urbina in Esmeraldas Province in the northwestern corner of Ecuador. These specimens may represent the species that we describe herein as $L$. cadenai.

Diagnosis.-A small Lonchophylla most easily distinguished from L. bokermanni, L. chocoana, L. handleyi, L. hesperia, $L$. orcesi, and $L$. robusta by its smaller size (GLS < 24.0). From other small Lonchophylla, L. cadenai can be distinguished by its short, brown dorsal pelage (unlike L. pattoni); relatively short skull (GLS < $22.6 \mathrm{~mm}$ - unlike L. concava, L. mordax) and forearm (FA $<33.0 \mathrm{~mm}$ - unlike $L$. dekeyseri, L. mordax); broad, inflated rostrum (unlike L. concava); strongly inflated postorbital region with small, but distinct lateral projections (unlike $L$. concava, $L$. dekeyseri, $L$. mordax, $L$. pattoni, L. thomasi); anterior placement of posterior border of infraorbital foramen (unlike L. concava, L. dekeyseri, $L$. mordax); P4 with obvious, rooted lingual cusp (unlike L. concava); lack of deep groove along midline of posterior palate (unlike L. concava); short, acutely Vshaped mesopterygoid fossa lacking median projection of palate (unlike $L$. concava, L. dekeyseri, L. mordax); broadly inflated pterygoid processes (unlike $L$. concava, L. dekeyseri, L. mordax); shallow basisphenoid pits separated by broad septum (unlike L. dekeyseri, L. mordax, L. pattoni, L. thomasi); short, robust dentary (unlike L. concava, L. pattoni) with low coronoid process and short articular process (unlike $L$. dekeyseri, $L$. mordax); p2 with posterior cusp (unlike $L$. concava); gap between i2 and canine about as wide as length of i2 (unlike $L$. concava).

Description.-Lonchophylla cadenai is one of the three smallest species in the genus, as gauged by GLS, HB, and FA 

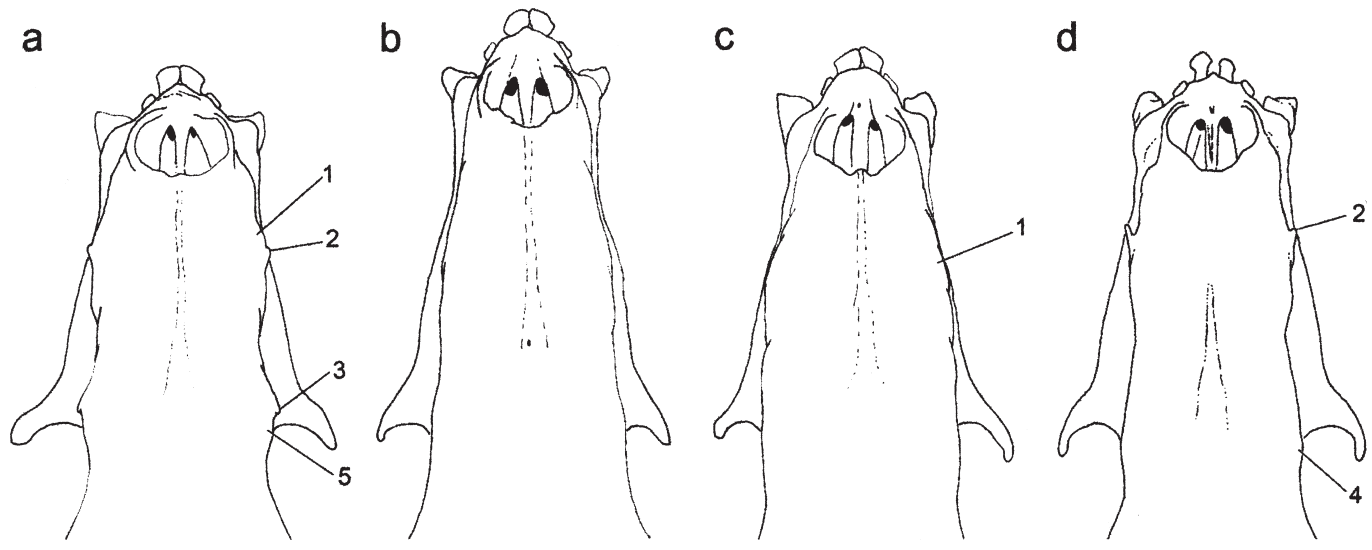

Fig. 11. Dorsal view of rostra of (a) L. cadenai, (b) L. concava, (c) L. dekeyseri, and (d) L. pattoni, illustrating inflated rostrum (1); projecting posterior margin of infraorbital foramen (2); lateral projections in postorbital area (3); and moderately (4) to strongly (5) inflated postorbital area.

(Table 2). Dorsal pelage typically $4-7 \mathrm{~mm}$ long, bicolored (Fig. 9) with paler bases (ca. 60\% of length) Light Ochraceous Buff to Ochraceous Tawny, darker tips from Dresden Brown on the lower back to Cinnamon Brown near the head; ventral pelage Buckthorn Brown to Cinnamon Brown, typically monocolored on the abdomen, but having darker tips near the chest. Genal vibrissae absent; three interramal vibrissae present; weakly-developed central rib of noseleaf extends to tip. Anterior edge of upper canine flat. In dorsal view, rostrum short and moderately broad; rostrum inflated above M1s, lateral margins convex; postorbital region strongly inflated, typically with small lateral projections (Fig. 11); posterior margin of infraorbital foramen typically projects beyond lateral outline of rostrum. In lateral view, posterior border of infraorbital foramen typically above anterior root of P4. In palatal view, obvious gaps between I1 and I2; P4 possesses obvious, rooted lingual cusp; upper molars large; postprotocrista of M1 and M2 joins posteriorly with base of metacone, posthypocrista and hypoconal basin absent; transition of posterior palate to postdental palate lacking deep midline groove; palate posterior to M3 short, equal to or less than half the length of M3; posteromedial edge of palate well posterior to optic foramen and near middle of sphenoidal fissure; mesopterygoid fossa short and acutely V-shaped anteriorly; anterior border of mesopterygoid fossa lacking median projection of palate; pterygoid processes greatly inflated, forming broad, flat ventral surface; basisphenoid pits shallow, intervening septum broad, rounded. Dentary short and deep; coronoid process low (slightly above level of articular condyle), broadly V-shaped; articular process short; p2 with well-defined posterior cusp similar to that of p3. In dorsal view, gap between i2 and canine typically equal to or narrower than length of $i 2$.

Comparisons.-From Lonchophylla bokermanni, L. chocoana, L. handleyi, L. hesperia, L. orcesi, L. robusta, and Platalina genovensium, $L$. cadenai is easily distinguished by its much smaller size (GLS $<24.0 ;$ FA $<35.0 ;$ HB $<60$ Table 1).

Lionycteris spurrelli: Lonchophylla cadenai differs in having a much shorter forearm, but averaging much larger in all linear dimensions of the cranium, including an obviously longer rostrum; dorsal hairs much paler basally than at tips; strongly inflated postorbital region 
with small lateral projections; more anteriorly located posterior border of infraorbital foramen that projects beyond lateral margin of rostrum; elongated and laterally compressed P3 and P4; P3 lacks a lingual cusp; more triangular upper molars; less highly domed midline of central palate; obviously convex posterolateral borders of palate; short, acutely Vshaped mesopterygoid fossa, lacking median projection of palate; inflated pterygoid processes; deeper basisphenoid pits separated by somewhat narrower septum; longer dentary with proportionally longer articular process; somewhat lower coronoid process and shallower upper sigmoid notch; elongate and laterally compressed p3 and p4, with low central cusp centered between roots; wider gap between i2 and canine.

Lonchophylla concava: Lonchophylla cadenai has shorter, broader, more inflated rostrum; more inflated postorbital region, with small, lateral projections; more anteriorly located posterior border of infraorbital foramen that projects beyond lateral margin of the rostrum; shorter, broader palate; obvious, rooted lingual cusp on P4; deep groove along midline of posterior palate lacking; short, acutely V-shaped mesopterygoid fossa lacking median projection of palate; inflated pterygoid processes; narrower septum separating basisphenoid pits; higher and narrower coronoid process; posterior cusp on $\mathrm{p} 2$; smaller gap between i2 and canine.

Lonchophylla dekeyseri: Lonchophylla cadenai has a shorter, broader, more inflated rostrum; more inflated postorbital region with small postorbital projections; more anteriorly located posterior border of infraorbital foramen that projects beyond lateral margin of rostrum; larger gap between I1 and I2; broader palate; short, acutely V-shaped mesopterygoid fossa, lacking median projection of palate; inflated pterygoid processes; broader, shallower basisphenoid pits, separated by a slightly broader septum; slightly lower and more pointed coronoid process with shallower upper sigmoid notch.

Lonchophylla mordax: Lonchophylla cadenai has a slightly longer, broader rostrum; strongly inflated postorbital region with small postorbital projections; more anteriorly located posterior border of infraorbital foramen that projects beyond lateral outline of rostrum; larger gap between I1 and I2; broader palate; short, acutely V-shaped mesopterygoid fossa, lacking median projection of palate; inflated pterygoid processes; broader, shallower basisphenoid pits; slightly lower, more pointed coronoid process and shallower upper sigmoid notch; longer articular process.

Lonchophylla thomasi: Lonchophylla cadenai has more robust cranium; broader, more inflated rostrum; postorbital region more inflated, with small, distinct postorbital projections; slightly broader, flatter ventral surfaces of inflated pterygoid processes; slightly shallower basisphenoid pits separated by a somewhat broader septum.

Lonchophylla pattoni: Lonchophylla cadenai has darker dorsal pelage; shorter, broader rostrum that is inflated above M1s; more inflated postorbital region, with small, distinct postorbital projections; larger molars, with larger protoconal basins; somewhat more inflated pterygoid processes having broader, flattened ventral surfaces; shallower basisphenoid pits with slightly broader intervening septum; shorter, broader dentary with slightly narrower, more pointed coronoid process; shorter articular process; smaller gaps between lower premolars.

Multivariate analyses.-Lonchophylla cadenai is most similar in size and morphology to L. thomasi, so we carried out PCAs comparing five $L$. cadenai with 41 female and 71 male $L$. thomasi from throughout the distribution of that spe- 


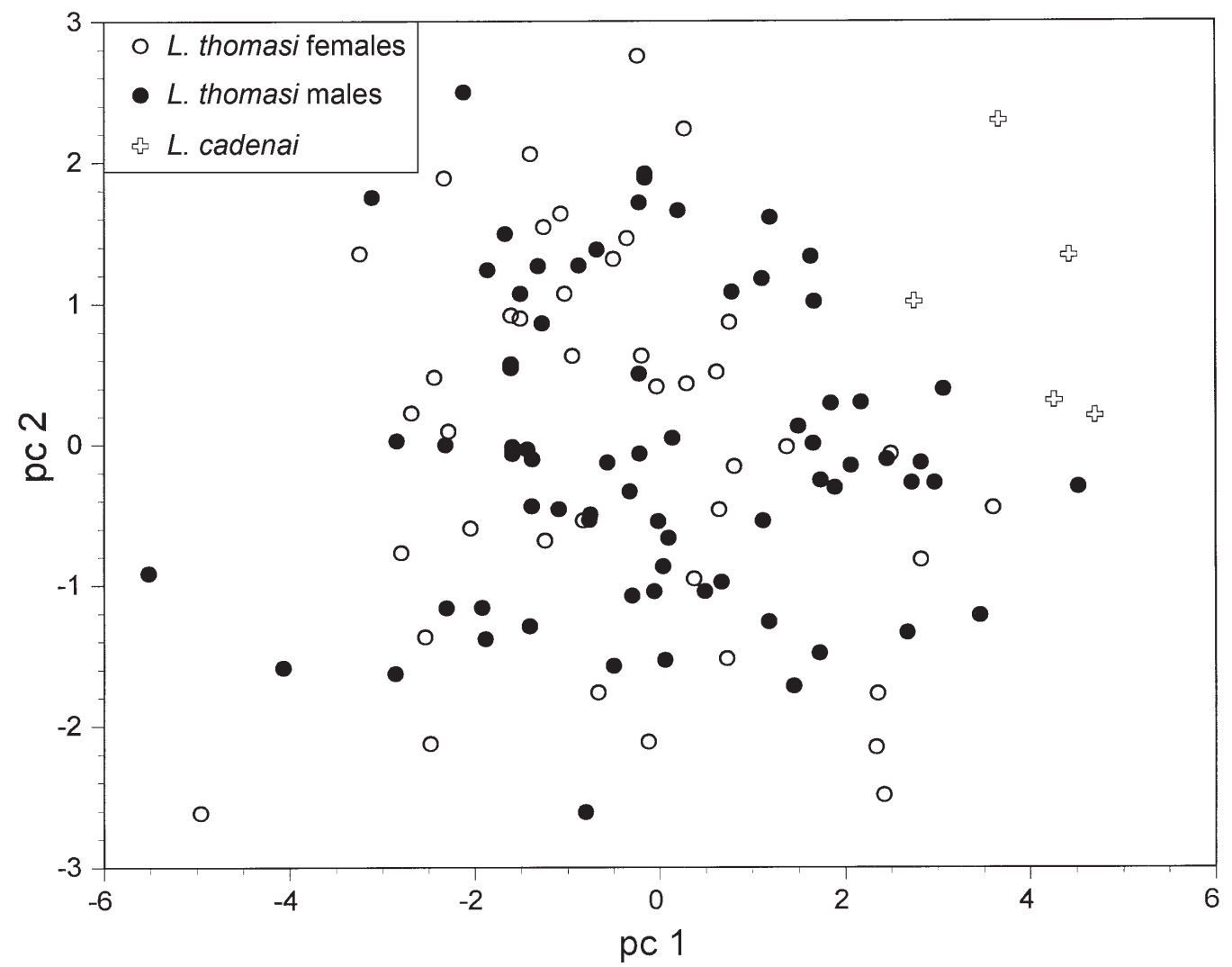

Fig. 12. Plot of scores on first two axes from PCA of 10 variables from 5 L. cadenai and 41 female and 71 male L. thomasi (Table 7).

cies. In the plot of factor scores on the first two factor axes (Fig. 12), specimens of $L$. cadenai plot among the largest $L$. thomasi (PC 1-Table 7), and they are among those with the broadest crania (PC 2). Individual $L$. thomasi that approach $L$. cadenai in size include females from Bolivia and Panama and males from Brazil, Panama, Peru, and Venezuela. Together, the two factors (overall size and relative breadth of cranium) serve to distinguish all five specimens of the new species from most $L$. thomasi. Along PC 3 (not plotted), which represents HCP, FA, and MM (Table 7), L. cadenai is distinguished by its relatively high coronoid process.

Remarks.-The holotype and five other individuals were captured by Maurice
Table 7.-Factor loadings for the first three axes from PCA of 10 variables from 5 L. cadenai and 112 L. thomasi (Fig. 12). Variables are ordered by weightings on PC 2.

\begin{tabular}{lccc}
\hline \multirow{2}{*}{ Variable } & \multicolumn{3}{c}{ Correlations } \\
\cline { 2 - 4 } & PC 1 & PC 2 & PC 3 \\
\hline BB & 0.311 & 0.445 & 0.008 \\
PO & 0.173 & 0.411 & 0.053 \\
MB & 0.389 & 0.293 & 0.134 \\
ZB & 0.364 & 0.236 & 0.013 \\
MM & 0.241 & 0.147 & -0.449 \\
FA & 0.199 & -0.130 & -0.697 \\
HCP & 0.321 & -0.150 & 0.512 \\
GLS & 0.431 & -0.214 & 0.033 \\
TR & 0.307 & -0.381 & -0.124 \\
PL & 0.330 & -0.490 & 0.114 \\
Eigenvalue & 4.1229 & 1.4567 & 1.0875 \\
Proportion of & $41.2 \%$ & $14.6 \%$ & $10.9 \%$ \\
$\quad$ variation & & & \\
\hline
\end{tabular}


Earl Thomas from Tulane University during his Ph.D. research on reproductive cycles of Neotropical bats. He conducted field work across from the village of Zabaletas along the east bank of the Río Zabaletas, a clear, gravel-bottomed tributary of the Río Anchicaya (Thomas 1972). This site is on the Pacific coastal plain in Premontane Rain Forest (IGAC 1988). Mean annual temperature in the region is ca. $25.5 \pm 2^{\circ} \mathrm{C}$, and mean annual rainfall exceeds $7000 \mathrm{~mm}$. The two periods of greatest rainfall are in mid-MarchMay and September-December; the driest period is January-March. The study site encompassed a gravel bar at the edge of the river and extended inland across a lightly-forested flood plain and approximately $100 \mathrm{~m}$ into dense rain forest on an older river terrace. Dominant plants on the flood plain were introduced breadfruit (Artocarpus incisa-Moraceae) and banana and plantain (Musa-Musaceae), as well as chontadura palm (Bactris gasipaes-Palmae), Cecropia (Cecropiaceae), and platanillo (Heliconia-Heliconiaceae). Vegetation in the forest included a variety of palms (Palmae), two species of figs (Ficus-Moraceae), Miconia (Melostomaceae), Inga (Fabaceae), Cassia (Fabaceae), and Piper (Piperacea). Trees in the forest had a dense cover of epiphytes and lianas (Thomas 1972). Mist-netting for bats generally was carried out from dusk to midnight for four consecutive nights between day 20 and 30 of each month from September 1966 through August 1967. A total of twelve $10 \times 2 \mathrm{~m}$ nets (six at ground level, six with their tops at $4 \mathrm{~m}$ above the ground surface) were set on the gravel bar, between trees on the flood plain, and in clearings and along trails on the forested terrace (Thomas 1972). Six adult $L$. cadenai were captured between February and June 1967: a male on 18 February, a female in March, two females and a male on 17 April, and a female on 14 June. In addition, a male $L$. concava
(USNM 483360) was netted at the site on 18 November 1966, and two female $L$. chocoana (USNM 483361, 483362) were taken on 18-19 April 1967, indicating that the three species of Lonchophylla were syntopic at this site. The bat fauna recorded near Zabaletas includes at least 35 species. One additional specimen of $L$. cadenai (USNM 338726) was captured in January or February 1964 by Dr. José Ignacio Borrero H. at Bajo Calima, near Buenaventura.

In French Guiana, Lonchophylla thomasi was caught primarily in ground-level $(0-2 \mathrm{~m})$ mist nets and rarely in canopy nets, suggesting that it typically flies in the lower forest strata (Brosset \& CharlesDominique 1990, Simmons \& Voss 1998). Despite this, species of Lonchophylla are uncommonly captured using traditional mist-netting techniques. Thomas (1972) netted 1646 individual bats at Zabaletas, of which only 9 were Lonchophylla. Another study of chiropteran abundance and reproductive activity that was conducted east and south of Buenaventura, Colombia, in August 1964 yielded several hundred captures but only a single $L$. chocoana (Arata \& Vaughn 1970). Similarly, a sample of 9011 specimens (USNM) captured throughout Colombia by Cornelis J. Marinkelle of Universidad del Valle during a multi-year study of invertebrate, fungal, and bacterial parasites associated with bats included only six Lonchophylla ( 2 L. concava, 4 L. robusta). Ascorra et al. (1994) reported only 32 captures of Lonchophylla among 2489 bats of 62 species netted at Jenaro Herrera, Loreto, Peru. In contrast, Brosset \& Charles-Dominique (1990) considered $L$. thomasi to be common in primary and secondary forest in French Guiana, and Simmons \& Voss (1998) recorded 55 captures of $L$. thomasi (36 in ground-level mist nets, 1 in an elevated mist net, 18 at roosts) among 3126 captures of 102 species of bats at Paracou, French Guiana. 


\section{Phylogenetic Analyses}

Our phylogenetic analyses of the matrix of 65 characters yielded contrasting results but generally supported monophyly of the Lonchophyllini. Parsimony analysis provided a completely resolved tree that showed a clear pattern of relationships among all species, both in the ingroup and the outgroup (Fig. 13). However, most branches were supported by few unambiguous characters. This fact was reflected in the bootstrap analysis, which provided little resolution and resulted in a polytomy within the Lonchophyllini with no wellsupported branches.

The single shortest tree from the parsimony analysis (Fig. 13) is similar to the strict consensus tree of Dávalos \& Jansa (2004: Fig. 4) in several respects. Both trees exhibit a strong, early divergence within the Lonchophyllini, and both show Lonchophylla to be paraphyletic with respect to two other genera within the Lonchophyllini. Both analyses also support close relationships among the species $L$. chocoana, L. handleyi, and L. robusta. The similarities end there. The analysis of Dávalos \& Jansa (2004) indicates a close relationship of $L$. concava (under the name L. mordax) with the $L$. chocoana / L. handleyi / L. robusta clade and that a deep division exists between this grouping and another that includes $L$. thomasi and Platalina. In contrast, our analysis suggests a close relationship between the $L$. thomasi group and the L. chocoana / L. handleyi / L. robusta clade, and the deep division occurs between that grouping and a clade that includes $L$. concava with Platalina. Also, Dávalos \& Jansa (2004) show Lonchophylla to be paraphyletic with respect to both Lionycteris and Platalina. In contrast, our analysis suggests that Lionycteris is the sister taxon to all other Lonchophyllini and that Lonchophylla is paraphyletic instead with respect to Platalina and Xeronycteris. Both studies raise the tantalizing possibility of Platalina being paraphyletic with respect to Lonchophylla, and therefore, potentially congeneric with some or all members of that genus. That hypothesis awaits a more complete character and taxon sampling for testing.

Our bootstrap tree preserves only a few branches, and even these are marked by low and moderate levels of support. There was moderate to low support $(81 \%)$ for conservation of the Lonchophyllini. Within the Lonchophyllini, there was moderate bootstrap support $(91 \%)$ for the cohesiveness of a clade consisting of the two new species and L. thomasi. Low support values (68-71\%) marked a sister relationship between $L$. pattoni and $L$. thomasi within that clade, as well as other sister group relationships between $L$. handleyi and $L$. robusta and between what appear to be the two most morphologically-derived taxa, Platalina genovensium and Xeronycteris vieirai. The lack of greater resolution in the bootstrap tree reflects the low number of morphological characters that we were able to code within the ingroup; poor character sampling, particularly among the less wellknown species; and homoplasy among the morphological characters we were able to code (Table 8 ). Clearly much remains to be learned about these highly-derived, nectar-feeding bats.

Key to the Smaller Lonchophyllini

1. Greatest length of skull (GLS) $>24.5$ mm (24.9-33.7) ... larger Lonchophyllini (Platalina genovensium, Xeronycteris vieirai, Lonchophylla bokermanni, L. chocoana, L. handleyi, L. hesperia, L. orcesi, and L. robusta).

$1^{\prime}$. GLS $<24.5 \mathrm{~mm}$ (smaller Lonchophyllini) .............. 2

2. Rostrum relatively short; internal cusp present on P3 and P4; p3 and p4 short and broad; central cusps of p3 and p4 high and narrow, offset laterally in occlusal view from ante- 


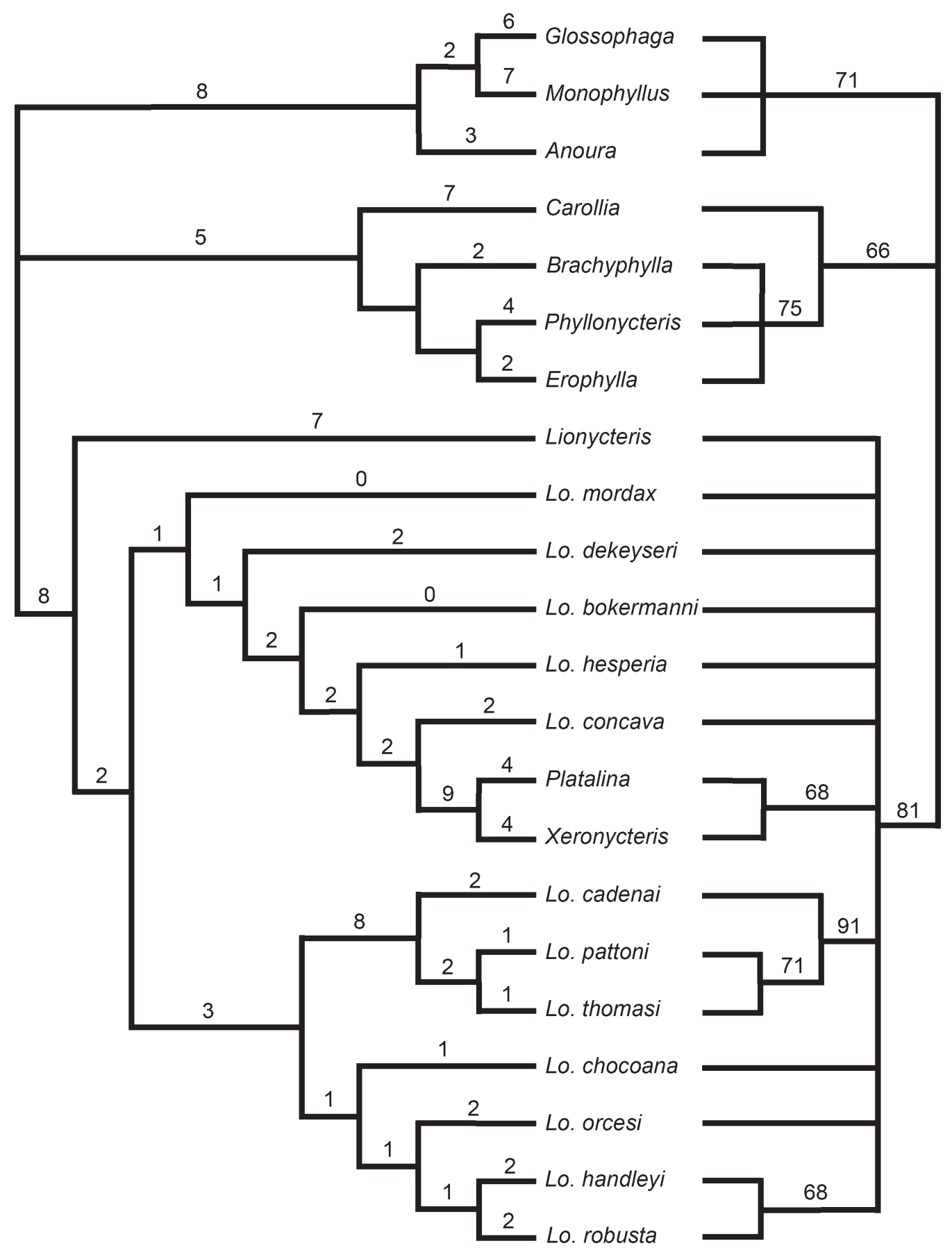

Fig. 13. Trees resulting from phylogenetic analysis of Lonchophyllini, using matrix of 65 characters. Single shortest tree from parsimony analysis (left). Numbers of unambiguous changes given above each branch. Tree statistics: length $=193 ; \mathrm{CI}=0.4767 ; \mathrm{RI}=0.6599 ; \mathrm{RC}=0.3146 ; \mathrm{HI}=0.5233$; rescaled $\mathrm{CI}=$ 0.4740 ; rescaled $\mathrm{HI}=0.5260 ; \mathrm{G}$-fit $=-45.501 ; F$-value $=1676 ; F$-ratio $=0.6315$. Bootstrap majority consensus tree (right). Bootstrap supports $>50$ listed above each branch; branches with supports $\leq$ 50 collapsed. 


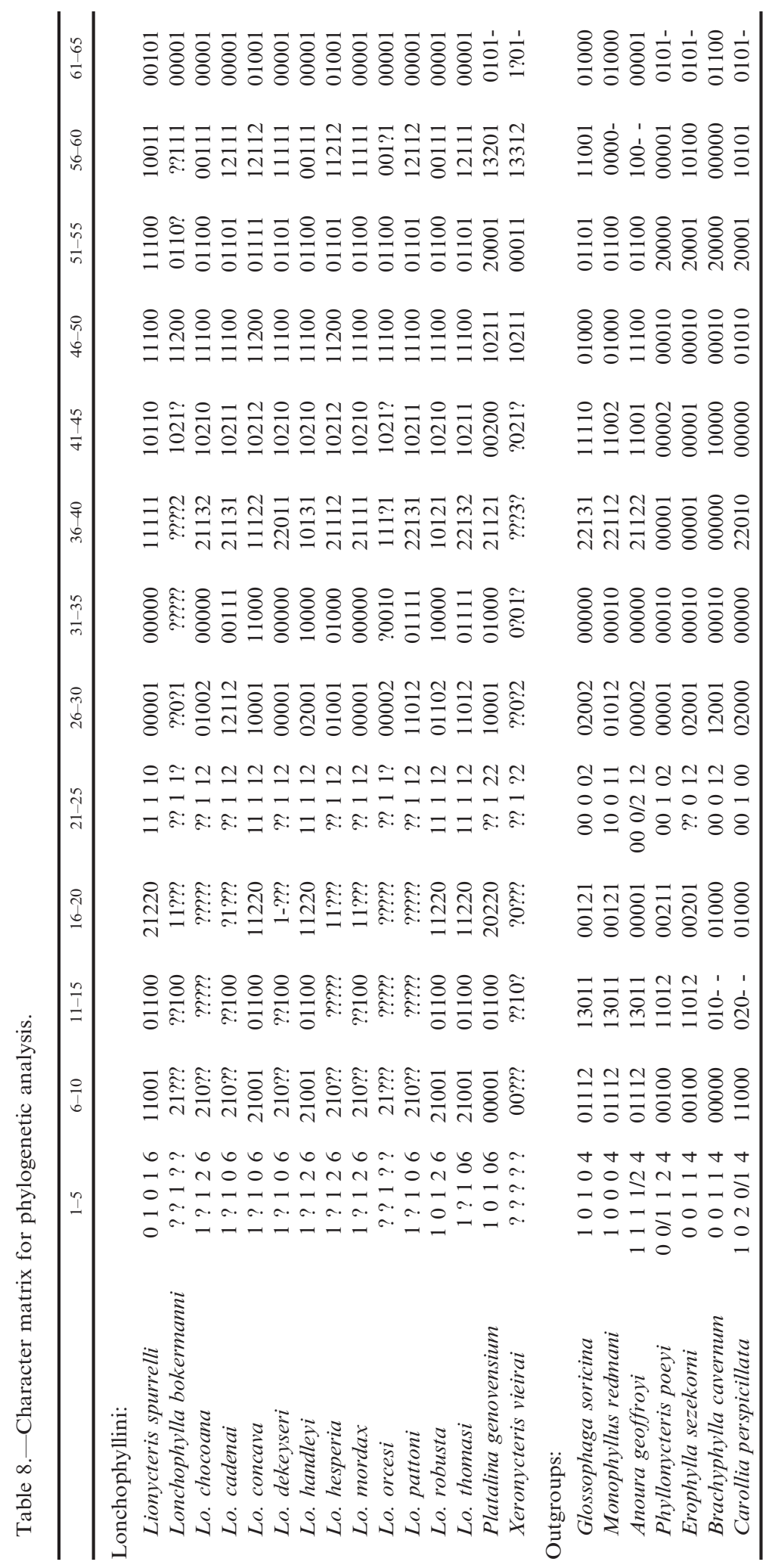


rior and posterior cusps; GLS $<21.0$ (19.0-20.7) . . . L Lionycteris spurrelli

$2^{\prime}$. Rostrum relatively long; internal cusp always absent on P3; p3 and p4 long and laterally compressed; central cusps of p3 and p4 relatively low and broad, in same plane as anterior and posterior cusps in occlusal view; GLS $=19.5-24.0$ (Lonchophylla) $\ldots$

3. Mesopterygoid fossa short, its anterior margin acutely $\mathrm{V}$-shaped and lacking medial projection of palate; pterygoid processes inflated; basisphenoid pits deep; posterior margin of infraorbital foramen anterior to posterior root of $\mathrm{P} 4$; large, obvious gap between I1 and I2; coronoid process low; GLS $<23.0$; length of forearm $(\mathrm{FA})<35.0$ ( $L$. thomasi

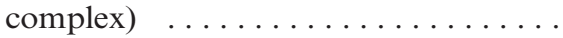

3'. Mesopterygoid fossa long, its anterior margin U-shaped or W-shaped and often with medial projection of palate; pterygoid processes narrow, not obviously inflated; basisphenoid pits shallow or deep; posterior margin of infraorbital foramen posterior to anterior root of $\mathrm{P} 4$; gap between I1 and I2 may be large or small; coronoid process high or low; GLS $=22.0-24.4 ; \mathrm{FA}=32.3-37.7 \ldots \ldots$

4. Rostrum inflated above M1s; postorbital region strongly inflated and with small lateral projections; septum between basisphenoid pits broad; $\mathrm{GLS}=21.4-22.5 ; \quad \mathrm{FA}=31.4$ $32.7 \ldots \ldots \ldots \ldots \ldots \ldots$ L. cadenai

$4^{\prime}$. Rostrum and postorbital region narrower, only slightly inflated; postorbital region lacking lateral projections; septum between basisphenoid pits narrow .............

5. Larger; dorsal pelage reddish brown; posterior margin of infraorbital foramen between P3 and P4; dentary long, slender with low, broadly rounded coronoid process; p3 isolated from $\mathrm{p} 2$ and $\mathrm{p} 4$ by large gaps; $\mathrm{GLS}=22.3 ; \mathrm{FA}=34.1 \quad \ldots \quad$ L. pattoni

5'. Smaller; dorsal pelage dark brown; posterior margin of infraorbital foramen typically above P4; dentary moderately long and deep; roundly pointed coronoid process; narrow gaps separate p2, p3, and p4; GLS $=19.5-22.2 ; \mathrm{FA}=29.8-34.4 \ldots$. . . . . . . . . . . . L. thomasi

6. Rostrum and postorbital region narrow, uninflated; large, obvious gap between I1 and I2; medial cusp absent from $\mathrm{P} 4$; deep midline groove on posterior palate; palate posterior to M3 much longer than 1/2 the length of M3; basisphenoid pits shallow, with broad intervening septum; coronoid process low; articular process long; p2 lacking posterior cusp; GLS $=22.2-24.0 ;$ FA $=$ $32.3-34.7 \ldots \ldots \ldots \ldots \ldots$ L. concava

6'. Rostrum and postorbital region moderately inflated; gap between I1 and I2 narrow; P4 with medial cusp; no deep midline groove on posterior palate; palate posterior to M3 less than $1 / 2$ the length of M3; basisphenoid pits deep, with narrow intervening septum; coronoid process high; articular process short; p2 with low posterior cusp ...........

7. Upper canines distinctly grooved along anterior surface; smaller cranially (GLS $=22.0-22.8 ; \mathrm{MM}=4.8$ 5.2), but with proportionally longer forearm $(\mathrm{FA}=34.0-37.7)$, such that the quantity [(GLS x MM) / FA] < 3.20 (range $=2.94-3.15, n=$ 4) $\ldots \ldots \ldots \ldots \ldots \ldots$ L. dekeyseri

$7^{\prime}$. Upper canines with convex anterior surface-not grooved; larger cranially $(\mathrm{GLS}=22.0-24.0 ; \mathrm{MM}=5.0-5.5)$ but with proportionally shorter forearm $(\mathrm{FA}=33.5-37.8)$, such that the quantity $[($ GLS x MM) / FA] $>3.15$ (range $=3.20-3.72, n=23) \quad \ldots \quad$ L. mordax

\section{Acknowledgments}

We are grateful to Alfred L. Gardner for sharing his comprehensive knowledge of Neotropical bats with us. Carla Dove kindly permitted access to the USNM Feather Identification Lab's MacIntosh computer resources for phylogenetic analyses. William E. Duellman, Mark S. Hafner, and Maurice E. Thomas pro- 
vided additional specimen and locality data that were particularly helpful to us. The following curators and collection staff graciously provided access to specimens under their care: Darrin Lunde, Nancy B. Simmons, Robert S. Voss, and Eileen Westwig (AMNH); Suzanne B. McLaren (CMNH); John B. Iverson (EC); Lawrence R. Heaney, Bruce D. Patterson, and William S. Stanley (FMNH); Jim Dines (LACM); Mark S. Hafner (LSUMZ); Joseph A. Cook (MSB); Barbara Lundrigan (MSU); Christopher J. Conroy and James L. Patton (MVZ); Robert J. Baker and Heath Garner (TTU); Philip Myers (UMMZ). Gary R. Graves's editorial insights and organizational skills are much appreciated. Al Gardner, Bruce Patterson, Ronald H. Pine, and an anonymous reviewer provided valuable comments, suggestions, and additional insights on an earlier version of this manuscript that greatly improved the quality of the final work. Any subsequent errors are our own.

\section{Literature Cited}

Albuja, V. L. 1999. Murciélagos del Ecuador. Second edition. Cicetronic Companía, Limitada, Quito, Ecuador, 288 pp.

, \& A. L. Gardner. 2005. A new species of Lonchophylla Thomas (Chiroptera: Phyllostomidae) from Ecuador.-Proceedings of the Biological Society of Washington 118: 442-449.

Allen, G. M. 1908. Notes on Chiroptera.-Bulletin of the Museum of Comparative Zoology 52:25-63.

Allen, J. A. 1904. New bats from tropical America with note on species of Otepterus.-Bulletin of the American Museum of Natural History 20:227-237.

Anderson, S. 1997. Mammals of Bolivia, taxonomy and distribution.-Bulletin of the American Museum of Natural History 231:1-652.

Arata, A. A., \& J. B. Vaughn. 1970. Analyses of the relative abundance and reproductive activity of bats in southwestern Colombia.-Caldasia 10:517-528.
Ascorra, C. F., D. L. Gorchov, \& F. Cornejo. 1994. The bats from Jenaro Herrera, Loreto, Peru.Mammalia 57:533-552. [Vol. 57, no. 4 is dated 1993; published 20 January 1994.]

Baker, R. J., C. A. Porter, J. C. Patton, \& R. A. Van Den Bussche. 2000. Systematics of bats of the family Phyllostomidae based on RAG2 DNA sequence.-Occasional Papers, Museum of Texas Tech University 202:i $+1-16$.

, S. R. Hoofer, C. A. Porter, \& R. A. Van Den Bussche. 2003. Diversification among New World leaf-nosed bats: An evolutionary hypothesis and classification inferred from digenomic congruence of DNA sequence.Occasional Papers, Museum of Texas Tech University $230: i+1-32$.

Benedict, F. A. 1957. Hair structure as a generic character in bats.-University of California Publications in Zoology 59:285-548.

Brosset, A., \& P. Charles-Dominique. 1990. The bats from French Guiana: A taxonomic, faunistic and ecological approach.-Mammalia 54:509-560.

Carstens, B. C., B. L. Lundrigan, \& P. Myers. 2002. A phylogeny of the Neotropical nectarfeeding bats (Chiroptera: Phyllostomidae) based on morphological and molecular data.-Journal of Mammalian Evolution 9: 23-53.

Dávalos, L. M. 2004. A new Chocoan species of Lonchophylla (Chiroptera: Phyllostomidae).-American Museum Novitates 3426: $1-14$.

—, \& S. A. Jansa. 2004. Phylogeny of the Lonchophyllini (Chiroptera: Phyllostomidae).- Journal of Mammalogy 85:404-413.

Duellman, W. E. 2005. Cusco Amazónico: The lives of amphibians and reptiles in an Amazonian rainforest. Comstock Publishing Associates, Ithaca, New York, xv + 433 pp.

_ , \& J. E. Koechlin. 1991. The Reserva Cuzco Amazónico, Peru: Biological investigations, conservation, and ecotourism.-Occasional Papers of the Museum of Natural History, University of Kansas 142:1-38.

Galaz, J. L., J. C. Torres-Mura, \& J. Yáñez. 1999. Platalina genovensium (Thomas, 1928), un quiróptero nuevo para la fauna de Chile (Phyllostomatidae: Glossophaginae).-Noticiario Mensual, Museo Nacional de Historia Natural 337:6-12.

Gimenez, E. A., H. Ferrarezzi, \& V. A. Taddei. 1996. Lingual morphology and cladistic analysis of the New World nectar-feeding bats (Chiroptera: Phyllostomidae).--Journal of Comparative Biology 1:41-64.

Goldman, E. A. 1914. Description of five new mammals from Panama.-Smithsonian Miscellaneous Collections 63:1-7. 
Gregorin, R., \& A. D. Ditchfield. 2005. New genus and species of nectar-feeding bat in the tribe Lonchophyllini (Phyllostomidae: Glossophaginae) from northeastern Brazil.- Journal of Mammalogy 86:403-414.

Griffiths, T. A. 1982. Systematics of the New World nectar-feeding bats (Mammalia, Phyllostomidae), based on the morphology of the hyoid and lingual regions.-American Museum Novitates 2742:1-45.

Handley, C. O., Jr. 1966. Checklist of the mammals of Panama. Pp. 753-795, in R. L. Wenzel and V. J. Tipton, eds., Ectoparasites of Panama. Field Museum of Natural History, Chicago, xii +861 pp.

Hill, J. E. 1980. A note on Lonchophylla (Chiroptera: Phyllostomatidae) from Ecuador and Peru, with the description of a new species.Bulletin of the British Museum of Natural History (Zoology) 38:233-236.

Holdridge, L. R. 1947. Determination of world plant formations from simple climatic data.Science 105:367-368.

, W. C. Grenke, W. H. Hatheway, T. Liang, \& J. A. Tosi, Jr. 1971. Forest environments in tropical life zones: A pilot study. Pergamon Press, New York, xxxii +747 pp.

IGAC (Instituto Geográfico Agustín Codazo). 1988. Suelos y bosques de Colombia. Santafé de Bogotá, 135 pp.

Koopman, K. F. 1993. Order Chiroptera. Pp. 137-241, in D. E. Wilson and D. M. Reeder, eds., Mammal species of the world: A taxonomic and geographic reference. Second edition. Smithsonian Institution Press, Washington, D.C.

-1994. Chiroptera: Systematics. Handbook of zoology, vol. VIII: Mammalia. Walter de Gruyter, New York, vii +217 pp.

Linares, O. J. 1998. Mamíferos de Venezuela. Sociedad Conservacionista Audubon de Venezuela, Caracas, 691 pp.

Maddison, W. P., \& D. R. Maddison. 1992. Macclade: Analysis of phylogeny and character evolution, version 3. Sinauer Associates, Sunderland, Massachusetts, 939 pp.

Pacheco, V., B. D. Patterson, J. L. Patton, L. H. Emmons, S. Solari, \& C. F. Ascorra. 1993. List of mammal species known to occur in Manu Biosphere Reserve, Peru.-Publicaciones del Museo de Historia Natural, Universidad Nacional Mayor de San Marcos 44:1-12.

Patterson, B. D., V. Pacheco, \& S. Solari. 1996. Distributions of bats along an elevational gradient in the Andes of south-eastern Peru.- Journal of Zoology (London) 240: 637-658.
Paynter, R. A., Jr. 1982. Ornithological gazetteer of Venezuela. Museum of Comparative Zoology, Harvard University, Cambridge, Massachusetts, $245 \mathrm{pp}$.

Paynter, R. A. Jr 1997. Ornithological gazetteer of Colombia. Second edition. Museum of Comparative Zoology, Harvard University, Cambridge, Massachusetts, $537 \mathrm{pp}$.

Phillips, C. J. 1971. The dentition of glossophagine bats: Development, morphological characteristics, variation, pathology, and evolution.University of Kansas Museum of Natural History, Miscellaneous Publication 54:1-138.

Reid, F. A. 1997. A field guide to the mammals of Central America \& southeast Mexico. Oxford University Press, New York, xviii +334 pp.

Ridgway, R. 1912. Color standards and color nomenclature. Privately published, Washington, DC, iii +43 pp.

Sazima, I., L. D. Vizotto, \& V. A. Taddei. 1978. Uma nova espécie de Lonchophylla da Serra do Cipó, Minas Gerais, Brasil (Mammalia, Chiroptera, Phyllostomidae).--Revista Brasiliera de Biologia 38:81-89.

Simmons, N. B. 2005. Order Chiroptera. Pp. 312-529, in D. E. Wilson and D. M. Reeder, eds., Mammal species of the world: A taxonomic and geographic reference. Third edition. Johns Hopkins University Press, Baltimore.

_ , \& R. S. Voss. 1998. The mammals of Paracou, French Guiana: A Neotropical lowland rainforest fauna. Part 1. Bats.Bulletin of the American Museum of Natural History 237:1-219.

Sokal, R. R., \& F. J. Rohlf. 1981. Biometry. Second edition. W. H. Freeman and Company, New York, $\mathrm{xx}+859 \mathrm{pp}$.

Swofford, D. L. 1998. PAUP*. Phylogenetic analysis using parsimony (*and other methods). Version 4. Sinauer Associates, Sunderland, Massachusetts.

Taddei, V. A., L. D. Vizotto, \& I. Sazima. 1983. Uma nova espécie de Lonchophylla do Brasil e chave para identificação das espécies do gênero (Chiroptera, Phyllostomidae).Ciência e Cultura 35:625-629.

Thomas, M. E. 1972. Preliminary study of the annual breeding patterns and population fluctuations of bats in three ecologically distinct habitats in southwestern Colombia. Ph.D. dissertation, Tulane University, vii + $161 \mathrm{pp}$.

Thomas, O. 1903. Notes on South-American monkeys, bats, carnivores, and rodents, with descriptions of new species.-Annals and Magazine of Natural History, series 7, 12: 455-464. 
1905. Suggestions for the nomenclature of the cranial length measurements and of the cheek-teeth of mammals.-Proceedings of the Biological Society of Washington 18:191-196. . 1913. A new genus of glossophagine bat from Colombia.-Annals and Magazine of Natural History, series 8, 12:270-271.

1928. A new genus and species of glossophagine bat, with a subdivision of the genus Choeronycteris.-Annals and Magazine of Natural History, series 10, 1:120-123.

Tosi, J. A. 1960. Zonas de vida natural en el Perú. Memoria explicativa sobre el mapa ecológico del Perú.-Instituto Interamericano de Ciencias Agrícolas de la OEA, Zona Andina, Proyecto 39, Programa de Cooperación Técnica, Boletín Técnico 5:vi + 271.

Voss, R. S., \& L. H. Emmons. 1996. Mammalian diversity in Neotropical lowland rainforests: A preliminary assessment.-Bulletin of the American Museum of Natural History 230:1-115.

Wetterer, A. L., M. V. Rockman, \& N. B. Simmons. 2000. Phylogeny of phyllostomid bats (Mammalia: Chiroptera): Data from diverse morphological systems, sex chromosomes, and restriction sites.-Bulletin of the American Museum of Natural History 248:1-200.

Woodman, N., R. M. Timm, R. Arana, C., V. Pacheco, C. A. Schmidt, E. D. Hooper, \& C. Pacheco, A. 1991. Annotated checklist of the mammals of Cuzco Amazónico, Peru.-Occasional Papers of the Museum of Natural History, University of Kansas 145:1-12.

Associate Editor: Gary R. Graves

\section{Appendix I}

Character Codings For Phylogenetic Analysis

External characters:

1. Pelage (Wetterer et al. 2000: character 1): differentiated into under hair and over hair (0); lacking over hair (1)

2. Majority of scale margins on hairs (Wetterer et al. 2000: character 4): entire (0); toothed [Wetterer et al. 2000: state 2] (1). Carstens et al. (2002: \#104) scored this for five species of Lonchophylla. They based their character, however, on (Wetterer et al. 2000), who derived it from Benedict (1957), who inspected only $L$. robusta.

3. Dorsal fur (Wetterer et al. 2000: character 5): unicolored (0); bicolored (1).

4. Genal vibrissae (Wetterer et al. 2000: character 12): absent (0); with single vibrissa in each cluster (1); two vibrissae in each cluster. We followed Dávalos \& Jansa (2004) in coding this character among Lonchophylla.

5. Interramal vibrissae (Wetterer et al. 2000: character 13): one vibrissa [Wetterer et al. 2000: state 2] (0); two vibrissae [Wetterer et al. 2000: state 4] (1); three vibrissae [Wetterer et al. 2000: state 6].

6. Central rib of noseleaf (Wetterer et al. 2000: character 21) (=Gregorin \& Ditchfield 2005: \#4): absent (0); restricted to proximal portion of spear (1); extends to distal tip of spear (2). We followed Dávalos \& Jansa (2004) in coding this character among Lonchophylla. Gregorin \& Ditchfield (2005) for L. mordax.

7. Internarial region (Wetterer et al. 2000: character 22): smooth (0); with line of papillae (1). Gregorin \& Ditchfield (2005: \#6).

8. Chin (Wetterer et al. 2000: character 32): without central cleft (0); with central cleft (1).

Hyoid musculature and tongue:

9. M. ceratohyoideus (Wetterer et al. 2000: character 95): does not insert on stylohyal (0); or partly inserts on stylohyal (1).

10. M. genioglossus (Wetterer et al. 2000: character 101): inserts into ventral surface of tongue along more than half of its length (0); insert into posterior half to third of ventral surface of tongue (1); inserts into posterior quarter of ventral surface of tongue (2). Although (Carstens et al. 2002: \#77) scored this for 5 species of Lonchophylla, they based their character on (Wetterer et al. 2000), who derived it from Griffiths (1982), who inspected only L. robusta.

11. Anterolateral slip of M. sphincter colli profundus (Wetterer et al. 2000: character 103): present (0); absent (1).

12. M. crocopharyngeus (Wetterer et al. 2000: character 106): consists of a single large slip (0); two slips (1); three slips (2); more than three slips (3).

13. Lingual sulci (Wetterer et al. 2000: character 112): absent (0); present on lateral surface of tongue (1). See also Gregorin \& Ditchfield (2005: \#1); Gimenez et al. (1996: \#2).

14. Hairlike papillae (Wetterer et al. 2000: character 114): confined to lateral margin of distal third of tongue, with a single line of papillae extending approximately to lateral circumvallate papillae (0); distributed around lateral margin and dorsum of distal third of tongue (1). Gregorin \& Ditchfield (2005: \#2); Gimenez et al. (1996: \#14).

15. Hairlike papillae of tongue (Wetterer et al. 2000: character 115): fleshy and conical (0); fleshy and conical with filamentous tips (1); cylindrical with ellipse-shaped distal end (2). Gimenez et al. (1996: \#14). 
16. Medial-posterior patch of anteriorly directed mechanical papillae of tongue (Wetterer et al. 2000: character 117): always absent (0); present in some individuals (1); always present (2). Dávalos \& Jansa (2004) considered this character equivocal for Lonchophylla.

17. Basketlike papillae of tongue (Wetterer et al. 2000: character 119): absent (0); present (1). Gregorin \& Ditchfield (2005: \#3); Gimenez et al. (1996: \#10).

18. Lingual papillae anterior to main papillae (Wetterer et al. 2000: character 125): three small papillae (0); one papilla (1); no papilla (2).

19. Primary horny papillae (Wetterer et al. 2000: character 127): flanked by a pair of smaller horny papillae (0); no smaller papillae (1).

20. Lingual arteries (Wetterer et al. 2000: character 128): paired, lingual veins not enlarged (0); single midline artery, lingual veins enlarged (1).

\section{Restriction sites:}

21. Restriction site 50 of transcribed portion of rDNA complex (Wetterer et al. 2000: character 146): present (0); absent (1)

22. Restriction site 53 (Wetterer et al. 2000: character 148): absent (0); present (1).

\section{Skull:}

23. Zygomatic arch (Wetterer et al. 2000: character 42): complete (0); incomplete (1); polymorphic within species (2).

24. Length of skull (relative to least postorbital breadth): short [mean GLS/PO < 4.8] (0); long [mean GLS/PO = 5.0-5.5] (1); very long [mean GLS/PO > 5.9] (2).

25. Length of rostrum relative to length of braincase: short-measured from position of cribiform plate, rostrum $<34 \%$ length of skull (0); long, 36-38\% (1); very long, $>39 \%$ (2).

26. Rostrum: slightly inflated (uninflated) (0); distinctly inflated (1).

27. Postorbital region: uninflated (0); slightly inflated (1); moderately inflated (2); strongly inflated (3).

28. Postorbital processes: absent (0); present (1).

29. Posterior margin of infraorbital foramen (Fig. 11): within margin of rostrum (0); forms laterally-projecting lip (1).

30. Position of posterior margin of infraorbital foramen: above posterior root of P3 (0); between P3 and P4 (1); above anterior root of P4 (2); between roots of P4 (3); above posterior root of P4 (4); between P4 and M1 (5); above anterior root of M1 (6); between roots of M1 (7).

31. Deep midline groove on posterior palate: absent (0); present (1).
32. Length of palate immediately posterior to M3: short, $\leq$ anterior-posterior length of M3 (0); long, >length of M3 (1).

33. Shape of mesopterygoid fossa: long, open, Ushaped or W-shaped anteriorly (0); short, acute V-shaped anteriorly (1).

34. Medial projection of palate into mesopterygoid fossa: present (0); absent (1).

35. Pterygoid processes: slender, uninflated (0); inflated (1).

36. Basisphenoid pits: very shallow (0); shallow (1); deep (2).

37. Septum between basisphenoid pits: very broad (0); broad (1); narrow (2).

38. Posterolateral border of palate: concave (0); convex, projecting into zygomatic space (1).

39. Position of posterior border of palate: posteromedial edge of palate well anterior to optic foramen (0); just anterior to or at posterior border of optic foramen (1); posterior to optic foramen and near anterior end of sphenoidal fissure (2); well posterior to optic foramen and near middle of sphenoidal fissure (3).

40. Coronoid process: very high (0); high (1); low [articular condyle nearly at level of tip of coronoid process] (2).

41. Height of articular condyle: about level with mandibular toothrow (0); above level of mandibular toothrow (1).

Upper dentition:

42. I1 (Wetterer et al. 2000: character 49): distinctly larger than I2 (0); about equal in size with I2 (1).

43. First upper incisors: not projecting anteriorly (0); projecting slightly anteriorly (1); projecting greatly anteriorly (2).

44. Gap between I1 and I2: narrow (0); broad (1).

45. Anterior edge of canine: rounded (0); flattened (1); grooved by wear against lower canine (2).

46. Parastyle on P3 (Gregorin \& Ditchfield 2005: character 14): low, but distinct (0); very low, indistinct (1).

47. Paracone on P4 (Gregorin \& Ditchfield 2005: character 16): low (0); high (1).

48. Lingual cusp on P4: rooted lingual expansion of cingulum (0); obvious lingual cusp (1); lingual cusp absent or reduced (2).

49. Ectoloph of M1-M2 (Wetterer et al. 2000: character 60): present (0); absent (1). See also Carstens et al. (2002: \#59).

50. M1 and M2 (Wetterer et al. 2000: character 73): in contact (0); not in contact, diastema present (1).

51. Parastyle on $\mathrm{M} 1$ and $\mathrm{M} 2$ : distinct and anterior to paracone (0); present, not anterior to paracone (1); absent (2).

52. Mesostyle on M1 and M2 (Gregorin \& Ditchfield 2005: character 20): absent (0); present (1). 
53. Metastyle on M1 (Gregorin \& Ditchfield 2005: character 22): reduced or absent (0); present (1).

54. Postprotocrista on M1, M2, and M3 (Gregorin \& Ditchfield 2005: character 23): present (0); reduced or absent (1).

55. Hypocone on M1, M2: present (0); absent (1).

56. Posthypocrista on M1, M2: present (0); absent (1).

57. Postprotocrista of M1 and M2: joins posteriorly with posthypocrista to form a long ridge extending just beyond metacone, small hypoconal basin present [outline of molar quadratic] (0); joins posteriorly with base of metacone, posthypocrista extremely reduced, vestige of hypoconal basin may be present [outline of tooth a rounded triangle] (1); joins posteriorly with base of metacone, posthypocrista and hypoconal basin absent [outline of tooth acutely triangular] (2); reduced or absent (3).

58. Position of M3 (Gregorin \& Ditchfield 2005: character 26): located entirely dorsal to base of anterior zygomatic process (0); part of M3 anterior to base of zygomatic process (1); M3 entirely anterior to zygomatic process (2); M3 much anterior to zygomatic process (3).

\section{Lower dentition:}

59. Lower incisors: not trifid (0); trifid (1). Dávalos (2004) described the i2s of $L$. handleyi and $L$. concava as bilobed rather than trilobed. Our inspections of specimens revealed that unworn incisors of $L$. concava are clearly trilobate, and we agree with Hill (1980) that the lower incisors in $L$. handleyi are faintly trilobate.

60. Gap between i2 and c1 (Gregorin \& Ditchfield 2005: character 28): absent, teeth essentially overlapping (0); small (1); large, at least as long as length of i2 (2).

61. Cingulum on c1 (Gregorin \& Ditchfield 2005: character 29): present (0); absent (1).

62. Posterior cusp (hypoconid) on p2: present (0); absent (1).

63. Elongate labial cusp (metacristid) on p3: absent (0); present (1).

64. Entoconid on $\mathrm{m} 1, \mathrm{~m} 2$, and $\mathrm{m} 3$ (Gregorin \& Ditchfield 2005: character 33): present (0); absent (1).

65. Strong pre-entocristid extending anteriorly from entoconid on $\mathrm{m} 1-\mathrm{m} 2$ : absent (0); present (1).

\section{Appendix II}

Specimens Examined

Lionycteris spurrelli (44).-BRAZIL: Espirito Santo: Santa Teresa (LACM 62878). COLOMBIA: Antioquia: Aljibes, 630 m (USNM 499297-499302);
La Tirana, $520 \mathrm{~m}$ (USNM 499296); Providencia, $610 \mathrm{~m}$ (USNM 499303-499305). GUYANA: Cuyuni-Mazaruni: N slope of Mt. Roraima (KU 160837, 160838). Potaro-Siparuni: $25 \mathrm{~km} \mathrm{WNW} \mathrm{of}$ Kurupukari, 90 m (KU 155138, 155140-155144, 155146, 155148). PERU: Madre de Dios: $102 \mathrm{~km}$ beyond Quincemil at $\mathrm{km}$ post 145, ca. $1000 \mathrm{ft}$ (LSU 20201); Pasco: San Juan, 900 ft (USNM 364346). VENEZUELA: Amazonas: Morocoy, $161 \mathrm{~m}$ (USNM 407827, 407830); Paria, 114 m (USNM 491695); Raya, 135 m (USNM 407826). Bolivar: El Paují, $851 \mathrm{~m}$ (USNM 444674 444678, 444680444683, 444685, 444690, 444692, 444693, 444703, 444704); $18.8 \mathrm{~km} \mathrm{NE}$ of Icabarú (USNM 444674); Independencia, $824 \mathrm{~m}$ (USNM 444673).

Lonchophylla cadenai (7).-COLOMBIA: Valle del Cauca: Bajo Calima (USNM 338726); 29 km SE Buenaventura, $75 \mathrm{~m}$ (USNM 446481, 446482, 483359-holotype, 483363-483365).

Lonchophylla chocoana (3).-COLOMBIA: Valle del Cauca: $29 \mathrm{~km}$ SE Buenaventura, 75 m (USNM 483361, 483362). ECUADOR: Esmeraldas: Los Pambiles (USNM 575171).

Lonchophylla concava (20).-COLOMBIA: Valle del Cauca: $29 \mathrm{~km}$ SE Buenaventura, 75 m (USNM 483360). COSTA RICA: Puntarenas: Corcovado National Park, near Sirena Station (USNM 565809). ECUADOR: Pichincha: $47 \mathrm{~km} \mathrm{~S}$ of Santo Domingo (USNM 528494-528500). PANAMA: Chiriquí: $1 \mathrm{mi}$ E of Cuesta de Piedra, $2800 \mathrm{ft}$ (USNM 331254). Darién: Cana, $2000 \mathrm{ft}$ (USNM 179621-holotype); Tacarcuna Village Camp, 3200 ft (USNM 309384-309389). San Blas: Armila (USNM 335181, 335182); Puerto Obaldía (USNM 335179).

Lonchophylla dekeyseri (4).-BOLIVIA: Santa Cruz: Huanchaca, Site I, 508 m (USNM 584472, 584473). BRAZIL: Bahia: Lamaras, 300 m (USNM 123392). Pernambuco: Buíque (MSU 16411).

Lonchophylla handleyi (6).-PERU: Cusco: Ridge Camp, 1000 m (USNM 588021). Huánuco: 6 km N of Tingo María (CM 98631, 98632). Junín: $13 \mathrm{mi} \mathrm{N}$ La Merced (AMNH 230215); 2 km NW San Ramón, 2900 ft (AMNH 230214). Pasco: San Juan (USNM 364347).

Lonchophylla hesperia (2).-PERU: Amazonas: $3.5 \mathrm{~km}$ E junction B Grande \& B rds (LACM 38848). La Libertad: Trujillo (USNM 283177).

Lonchophylla mordax (28).-BRAZIL: Bahia: Cidade da Barra (AMNH 235608; USNM 238008); Fazenda Flamengo (CM 99413, 99414). Ceará: $4 \mathrm{~km} S E$ of Nova Olinda (CM 99415). Pernambuco: Fazenda Cantareno (CM 99416); Fazenda Guaraní (CM 99417); Fazenda Maniçoba (CM 99418, 99419); Fazenda Pomonha (CM 99420, 99421); Serrote das Lajes (CM 99422, 99425-99437); Serrote Gambá (CM 99444, 99446); Serrote Gritadeira (CM 99448). 
Lonchophylla pattoni (1).-PERU: Río Madre de Dios: Reserva Cusco Amazónico, $200 \mathrm{~m}$ (KU 144232-holotype).

Lonchophylla robusta (37). COLOMBIA: Tolima: Cunday (USNM 432178-432181); Melgar (AMNH 207820). COSTA RICA: Heredia: $1 \mathrm{~km}$ S, $11.5 \mathrm{~km}$ E San Miguel, $700 \mathrm{~m}$ (USNM 562767562773). ECUADOR: Unknown locality (USNM 522156). Guayas: Huerta Negra (USNM 498830, 498831, 522157, 534298-534300); San Rafael (USNM 498827-498829). Pastaza: Mera (USNM 548069). PERU: Huánuco: $5 \mathrm{~km} \mathrm{SW}$ of Tingo María, Cueva de las Lechuzas (EC 3719, 3720, 3914, 3915, 3918, 3922). VENEZUELA: Barinas: Altamira, $794 \mathrm{~m}$ (USNM 419413); $7 \mathrm{~km}$ NNE Altamira, $1070 \mathrm{~m}$ (USNM 419415, 419417); $2 \mathrm{~km}$ SW Altamira, $620 \mathrm{~m}$ (USNM 419418, 419419). Bolivar: Ciudad Bolívar (AMNH 16120-holotype); Zulia: Kasmera (USNM 419410); $10 \mathrm{~km} \mathrm{S,} 18 \mathrm{~km}$ W of Machiques, $270 \mathrm{~m}$ (USNM 419409).

Lonchophylla thomasi (157).-BOLIVIA: El Beni: $1.5 \mathrm{~km}$ below Costa Marques, Brazil (AMNH 209358); $7 \mathrm{~km} \mathrm{~N}$ Lagoinha (AMNH 210688). La Paz: $1 \mathrm{mi} \mathrm{W}$ of Puerto Linares (MSU 32858; TTU 34812). Pando: Agua Dulce, 160 m (AMNH 262429, 262434). Santa Cruz: Huanchaca I, 508 m (USNM 584474-584476). BRAZIL: Amapá: vicinity of Serra do Navio (USNM 597536, 597537). Amazonas: Manaus (USNM 530958); $80 \mathrm{~km} \mathrm{~N}$ of Manaus (USNM 530959-530962). Pará: 52 km SSW Altamira (USNM 549361-549364, 549366-549369); Belém (USNM 361570, 361571, 393013, 393014, 460097, 460098); Inajatuba (AMNH 95495, 95772); Limôatuba (AMNH 95493); Mocajuba (AMNH 97271, 97272). COLOMBIA: Amazonas: Leticia (TTU 8834, 8847); Isla Santa Sofia (TTU 9059). Putumayo: San Antonio, Río Guamués (FMNH 113421); Estación de Bombeo, Guamués (FMNH 113929). ECUADOR: Orellana: Río Yasuní (USNM 528325). Pastaza: Tiguino, $300 \mathrm{~m}$ $\left[1^{\circ} 07^{\prime} \mathrm{S}, \quad 76^{\circ} 57^{\prime} \mathrm{W}\right]$ (USNM 574510, 574511). FRENCH GUIANA: Saül (KU 135369-135371, 135400); Paracou (AMNH 266100, 266103, 266105, 266108, 266109, 266117, 267139, 267940, 267943). GUYANA: Barima-Waini: Baramita, $142 \mathrm{~m}$ (USNM 582299-582301). Potaro-Siparuni: Kurupukari, Base Camp, $70 \mathrm{~m}$ (KU 155157); $5 \mathrm{~km} \mathrm{SW}$ of Kurupukari, Giaconda Camp, 75 m (KU 155152155155); 25 km WNW of Kurupukari, 90 m (KU
155156). Upper Takutu-Upper Essequibo: Kuitaro River, near Miliwau Creek (USNM 338904, 338906). PANAMA: Bocas del Toro: Nuri, 2-25 m (USNM 575486, 575488-575491, 575493, 575494, 575496-575498). Darién: mouth of Río Paya (USNM 306582). San Blas: Armila (USNM 335180). PERU: Amazonas: Río Cenepa, vicinity of Huampami, $700 \mathrm{ft}$ (MVZ 153321); km 381.4 of Carretera Corral Quemado-Nazareth, ca. $900 \mathrm{ft}$ (LSU 18422). Cuzco: Armihuari, $545 \mathrm{~m}$ (USNM 582794); Pagoreni, 465 m (USNM 577763); 40 km by road E of Quincemil (LSU 18860). Huánuco: $6 \mathrm{~km} \mathrm{~N}$ of Tingo María (CM 98649). Madre de Dios: Hacienda Amazonia, $1050 \mathrm{~m}$ (FMNH 138911); Hacienda Erika, $350 \mathrm{~m}$ (MVZ 166627; UMMZ 160708, 160710); km 105, road from Puerto Maldonado to Quincemil, ca. $500 \mathrm{ft}$ (LSU 18861); Refugio Juliaca, $200 \mathrm{~m}$ (USNM 579632); Lago Sandoval (MVZ 157669). Loreto: San Jacinto, $175 \mathrm{~m}$ (KU 158056-158061); Teniente López, $175 \mathrm{~m}$ (KU 158062, 158063). Pasco: San Juan, $900 \mathrm{ft}$ (AMNH 230281); San Pablo, $900 \mathrm{ft}$ (AMNH 230282-230284). Puno: Fila Boca Guacamayo, $360 \mathrm{~m}$ (USNM 579631). Ucayali: Balta, $300 \mathrm{~m}$ (LSU 12096-12102, 14119, 14120, 16486-16488; MVZ 136425, 136431, 136432, 136434, 136435, 136437); $59 \mathrm{~km} \mathrm{SW}$ of Pucallpa (USNM 499018). SURINAME: Brokopondo: $8 \mathrm{~km} \mathrm{S,} 2 \mathrm{~km}$ W of Brownsweg (CM 63713, 63715). Marowijne: $3 \mathrm{~km}$ SW of Albina (CM 76778, 76779). Sipaliwini: Avanavero (TTU 33709); Bitagron (CM 63722, 63723); Sipaliwini Airstrip (CM 63721); $1 \mathrm{~km} \mathrm{~N}$ of Rudi Kappel Airfield, 300 m (CM 63716); Voltz Berg (CM 63725, 63726); $24 \mathrm{~km} \mathrm{~S}, 60 \mathrm{~km} \mathrm{E}$ of Apoera (CM 63717-63720); Raleigh Falls (CM 63724). VENEZUELA: T. F. Amazonas: Capibara, 130 m (USNM 415387, 415388); 5 km E San Carlos de Río Negro, 120 m (FMNH 137268, 137269); ca. $7 \mathrm{~km}$ E of San Carlos de Río Negro (USNM 560560); Raya, 135 m (USNM 407802, 407803); San Juan, $155 \mathrm{~m}$ (USNM 407798, 407799, 407801); Tamatama, 135 m (USNM 407796, 407797). Bolivar: Ciudad Bolívar (AMNH 16120-holotype); El Manaco, $150 \mathrm{~m}$ (USNM 385753); $50 \mathrm{~km} \mathrm{SE} \mathrm{El}$ Manteco, 350 m (USNM 385751, 385752); Santa Lucía de Surukún, 851 m (USNM 456537).

Platalina genovensium (1).-PERU: Arequipa: Caravelí (USNM 268765). 